Polloy, Puanding, and fewearoh

WORKING PAPERS

Agrtoultural Polloy

Agriculture and Rural

Dovelopmont Department

The World Bank

April 1988

WPS 6

\title{
Farm-Nonfarm Linkages
} in

\author{
Steven Haggblade, \\ Peter B. Hazell, \\ and James Brown
}

The links between agricultural growth and the rural nonfarm economy, known to be strong in Asia, are weaker in Africa but still important to the rural poor. Crucial for strengthening these links are policies and investments that (1) promote smallholders, (2) improve rural infrastructure, (3) encourage commerce and services, (4) foster the development of rural towns, and (5) explicitly recognize women as key actors in rural development. 


\section{Contents}

I. Introduction.................................. 1

II. Definitions.....................................

III. Importance of Nonagricultural Activities in Africa's

Rural Economy.................................... 4

A. Employment.................................. 4

B. Income ................................. 5

C. Income distribution............................ 5

IV. Characteristics of Rural Nonfarm Enterprises............. 6

A. size...................................... 6

B. Composition.................................. 7

C. Employment density............................... 7

D. Female participation......................... 8

V. Structural TGransformation by the Rural Monfarm Activity... 9

A. Megatrends................................... 9

B. Changes by gize and locality...................... 12

C. Effect of distance from urban centers................. 13

D. Changes over time................................ 13

E. Correlates of growth............................ 15

VI. Magnitude or the Farm-Wonfarm Linkages................... 18

A. Capital flows.................................. 18

3. Labor flows...................................... 19

C. Backward Linkages................................ 19

D. Forward linkages............................... 20

E. Consumption links............................... 21

F. Caution.......................................... 23

VII. Probable Magnitude of the Agricultural Growth

Multipliers......................................

A. Direct cross-regional estimation.................. 24

B. A model of regional agricultural multipliers......... 26

C. Macroeconomic consequences and simulations........... 30

vIII. Conclusions.................................... 31

A. Implications for policy....................... 31

B. Implications for research......................... 34

C. Magnitude of multipliera......................... 35 
Notes

Tables

Figures

References

Steven Hagoblade is Assistant Professor at Syracuse University, New York. Peter Hazel1 is a Senior Economist in the Agricultural Policies Division of the Agriculture and Rural Development Department, the World Bank. James Brown is the Agro-Industries Adviser, also of the Agriculture an Rural Development Department, the World Bank, Washington, DC.

The work for this paper was part of a study by the Bank's Agricultur and Rural Development Department on Sustainable Agricultural Growth in Africa 
FARM-NONFARM LINKAGES IN RURAL SUB-SAHARAN AFRICA I/

\author{
STEVE HAGGBLADE \\ Syracuse University \\ and \\ PETER HAZELL AND JAMES BROWN \\ The World Bank, Washington, DC
}

\title{
I. INTRODUCTION
}

Based largely on evidence from Asia, Johnston and Kilby (1975), Mellor (1976), and Mellor and Johnston (1984) argue that a development strategy focused on sma11 ferms w111 generate rapid, equitable and geographically dispersed growth because of labor Intensive IInkages with the rural nonfarm economy. Using examples fron India, Pakistan, and Taiwan, Jchnston and Kilby (1975) highlight the potential Importance of production linkages. They point to small farmer demand for fertilizer, construction inputs, and equipment and repair services provided by rural blacksmiths. But farmers also purchase consumer goods. Mellor (1976), Mellor and Lele (1973) and Hazell and Roell (1983), In particular, have called attention to the potential power of agricultural consumption linkages. They conclude that middle-sized peasant farmers--to a much greater extent than their large scale and urban counterparts--spend incremental income on labor-intensive rurally produced goods, thereby generating important second-round demand multipliers. Hirschman's (1958) early indictment of agriculture as a low-1inkage, underpowered engine of growth erred, according to Mellor (1376), because it ignored these important agricultural consumpticn linkages.

Several empirical studies have documented the power of farm-nonfarm Iinkages in Asia. Based on data from Indla, Rangarajan (1982) found that a one percent addition to the agricultural growth rate stimulated a 0.5 percent addition to the growth rate of industrial output, and a 0.7 percent addition to the growth rate of national income. Be1l, Hazell and 
Slade (1982), exanining rural growth linkages in the Muda Rivar Region of Helayeia, conpute an agriculturally induced rural income multiplier of 0.8 . Bmployment multipliers are also substantial. Evidence from the Philippines (Gibb, 1974) and Inaila (Krishna, 2976; Mellor and Mudahar, 1974) places agriculture-to-nonfarm employment elasticities between 1.0 and 1.3 . Although decomposttion of the growth multipliers is rare, Bell, Hazell, and Slade (1985), in their Muda study, do provide a breakdown, estinating the contribution of the consumer demand generated by agricultural growth to be double the production linkages.

As attention turns increasingly to Sub-Saharan Africa, government leaders and donors alike view small farwer agriculture as tha necessary centerplece of development efforts. Equity, nutrition anc 'ty considerations argue persuasively for such a focus. In add:_:n, many belleve that a small farmer strategy will generate maximum growth rates, Asia-style, through linkage multipliers with the rural economy.

But no one has yet marshalled the empirical evidence necessary for assessing the power of agricultural growth linkages in Africa. It may now be possible to do so given the accumulation, over the past 25 years, of a body of detalled survey work examining the structure of Africa's rural nonfarm economy. 2f This paper examines that evidence. First, it systematically reviews empirical evidence on the nature and magnitude of the African rural nonfarm economy. It then explores differences across locality size, across countries and over time, In an effort to assess 1ikely patterns of growth. A subsequent review of key production and consumption parameters allows an estimate of the magnitude of the agricultural growth multipliers in Africa. The paper concludes with a brief discussion of policles and programs that will be necessary if farmnonfarm growth linkages are to achieve their full potential. 


\section{DEFInITIONS}

Before embarking on a review of rural nonfarm activities, it is necessary to specify what we mean by both "rural" and "nonfarm" . Concepts and definitions of "rural", In particulur, vary dramatically, as Anderson and Loiserson (1980) and Chuta and Liedholm (1979) have emphasized. The progression from rural to urban traverses a continuum of settlement patterns, population and functional densitles, making any attempt to partition the universe necessarily arbitrary. Conceptually, we prefer to think of rursl as depending on the function more than the size of a locality. Like Gibb (1974) and Anderson and Leiserson (1980), we consider as rural any locallty that exists primarily to service an agricultural hinterland. In contrast, urban economies are driven by manufacturing, government or some other motor independent of agriculture. Given this view, "rural" aress may include towns of substantial size, perhaps as large as several hundred thousand. Adnittedly this definition is difficult to apply across a large number of countries, as it requires intimate knowledge of the reglonal economies of each. And in most cases, we remain prisoners of the ruralurban delineations made by those who have collected the economic data of interest in this review. In order to deal with this problem and also to emphasize the spatial features that are so important to the development of the rural nonfarm economy, we shall, wherever possible, provide analyses which highlight differences in nonfarm activitles across locality size and region.

"Nonfarm" activities include all economic activity other than crop and livestock production, encorpassing services, construction, mining, commerce and manufacturing. In this review, we follow convention and define nonfarm activities to also include agroindustrial activities which store, process and market agricultural commodities. 


\section{IMPORTAYCE OF MOR-AORICULTURAL ACTIVITIES IN AFRICA RURAL ECONOMT}

\section{A. Employment}

Respecting Individual country definitions of "rural", Table 1 indicates that rural nonfarm enterprises provide the primary source of employment for between 3 percent and 63 percent of the labor force in rural Sub-Saharan Africa. i! Although highly variable, nonfarm shares of rural employment typically fall in the 10-20 percent range, in contrast to the 20-30 percent figures comonly reported for Asia (Table 3 and Chuta and Liedholm, 1979). Figures from both continents should be viewed as minimum estimates because they frequently exclude rural towns (see Note 3 ).

Different perceptions of female participation in the work force contribute to the wide range in African rural nonfarm employment shares. In Western Nigeria and Benin, shares of nonfarm activity in rural employment attain 63 percent and 41 percent, respectively, because of high female participation rates and because survey designers in those countries have classified 75 to 85 percent of active women as working primarily outside of agriculture. At the other extreme, women in Chad appear to participate at low overall rates and virtually exclusively in agriculture. Whether these apparently wide variations stem from reporting biases (Simmons, 1976a; Haggblade, Hazell and Brown, 1987), seasonal variation or actual differences in women': participation rates, there can be no doubt that the role of women significantly affects assessments of the magnitude of rural nonfarm employment.

Seasonal and part-time nonfarm activities also generate significant amounts of rural employment, occupying between 7 and 30 percent of the rural labor force (Table 1). Because the overall level of nonfarm activity runs countercyclicaliy to the agricultural calendar, distinct seasonal rhythms characterize nonfarm employment, with nonagricultural activity reaching its peak in the dry season immediately after harvest 
(Ancey, 1974; Anderson and Leiserson, 1980; Chernicovsky et al., 1985; Delgado, 1979; ILO, 1985b; Lledholn and Chuta, 1976; Matlon at al., 1979; Mueller and Zevering, 1970; Horman, Simmons and Hays, 1982; Okafor, 1983; Thomi and Yankson, 1983). Focusing exclusively on agricultural households, farm management surveys in numerous 4 , ican countries have found 15 to 65 percent of farmers with secondary employment in nonfarm enterp:-ses, and time allocation studies of farm households have found 15 to 40 percent of total family working hours devoted to income generating nonfarm activities (Anthony et al., 1979; Cleave, 1974; Hill, 1977; ILO, 1985b and 1985c; Luning, 1967; Norman, 1972; Okafor, 1983).

B. Income

Africa's rural inhabitants typically derive between 25 and 30 percent of their income from nonfarm sources (Table 2). And because nonfarm activities are monetized to a much larger extent than is agricultural production, nonfarm earnings constitute an even larger share of cash income. Panel B of Table 2 indicates that nonagricultural income regularly accounts for 30 to 50 percent of rural cash incomes.

\section{c. Income Distribution}

Available data on African rural nonfarm earnings do not show the clear pattern of equity enhancement that analysts have regularly reported In Asian studies (e.g., Bell, Hazell and Slade, 1982; KIlby and Liedholm, 1986). Researchers in Northern Nigeria (Mation, 1979) and Lesotho (Van der Weil, cited in ILO 1982h) have found that high-income rural dwellers derive a greater share of their earnings from nonfarm sources than do the poor. Less detailed evidence from rural Tanzania (Collier, Radwan and Wangwe, 1986) and from farm families In Zambia (Ghal and Radwan, 1984), Uganda (ILO, 1985d) and Zimbabwe (Weinrich, 1975) suggest similarly Inequitable trends. But support for the equity enhancing view of rural nonfarm incomes does emerge from some studies: from rural Botswana 
(Botawana, 1976), Zaria Region, Northern Migeria (Matlon, Simmons and Hays, 1982), and farm households in Gambla (ILO, 1985b). Moreover, some activities, such as fenale-dominated food preparation, do appear conslstently to enhance Income equality (see Simons, 1976a; Norman, Simmons and hays, 1982; Botswana, 1976; and M111mo and Fisseha, 1986). Ultimately, even if the impact of nonfarm earnings on relative income equality is uncertain or negative, access to nonfarm earnings does nonetheless improve the absolute income levels of the poor.

\section{CHARACTERISTICS OF RORAL RORRARY EMTERPRISES}

\section{A. Stre}

Whether they use employment or capital investment as the yardstick, studies of African rural nonfarm activity overwheiningly conclude that nonfarm enterprises are small (see Page, 1979; Chuta and Lledholn, 1979; Anderson and Leleerson, 1980; Page and Steel, 1984; Lledholn and Mead, 1986). In countries such as Burkina Faso, Ghana, Kenya, Slerra Leone and Zambla, one-person enterprises constitute about half of all rural nonfarm enterprises; and well over 95 percent employ flve people or 1 ess (Wilcoc's and Chuta, 1982; Thomi and Yankson, 1985; Freeman and Norcliffe, 1985; W111Lams and McClintock, 1981; Liedholm and Chuta, 1976; Milimo and Fisseha, 1986).

The large-scale firms that do operate in rural areas are frequently linited to trading establishments--either distributors or wholesalers of major agricultural commodities--and resource-based menufacturers who take advantage of weight-reducing production processes or specialize in the preliminary processing of perishable commodities. Studies In Ghana (Andrae, 1981), Kenya (Freeman and Norcliffe, 1985), and Zaire (Congo, 1968) clearly point to the concentration of large-scale rural Industries in sawmiling, mining and food processing. 
Average fixed capital per enterprise cownonly ranges between $\$ 500$ and $\$ 4,000$ in African rural nonfarm ectivities. Enterprises such as grain ni118, sawmills and wholesaling require on the order of $\$ 1,000$ to $\$ 10,000$ per enterprise; while traditional crafts, personal services and repairs require capital in the range of only $\$ 50$ to $\$ 600$ (see Haggblade, Hazell and Brown, 1987; Haggblade, 1982; Wilcock and Chuta, 1981; Freeman and Norcliffe, 1985; and Lledholm and Chuta, 1976).

\section{B. Composition}

Aggregate employment data for rural Africa remain in ohort supply because most atudies have focused on linited portions of the rural economy, often on farm households; others, although interested in the nonfarm economy, rarely include comercial and service establishments, concentrating instead on manufacturing and repair enterprises. Nonetheless some avallable data, coming mainly from population conmuses do allow a comprehensive view of the rural economy (Table 3, Panel A). Anid wide vailation, these data indicate that comercial extabliahnents typically predominate, employing 30-40 percent of the rural nonfarm workforce. Services and manufacturing comprise about 25 percent each, with construction and mining accounting for the remainder. The data in Table 4 indicate that, within manufacturing, food preparation, tailoring, carpentry and metal working activities predominate.

\section{Employment Density}

While a steady stream of micro research has greatly increased our understanding of the African rural nonfarm economy over the past 25 years, differences in survey coverage complicate cross-country comparisons. They nake it difficult to meaningfully compare employment percentages across surveys, because activity shares are computed as percentages of different bases depending on the comprehensiveness of the survey coverage. One solution to this problem--a solution adopted by steel (1979), K1lby (1987) 
and World Bank (1983)--1s to compute employment densities per 1,000 population. Because density seasures all surveyed activitios against a comnon yardstick, population, this procedure allowe comparison of absolute Intensity levels for all activities enunerated, even if a survay's coverage 1s only partial. This approach is taken throughout much of this paper, expecially where we explore features of atructural transformation using comparative data from studies with differing survey wethodologies.

The nonfarm employment densities in Table 3 provide tantalizing Intelal insighta into differences in the Asian and African rural : . Earm sec'ors. The data in Panel B suggest that Asian rural nonfarm employnent densities commonly 11e in the range of 80 to 140 per 1,000 population, while the African densities only reach this level in West Africa. Elsewhere they are much lower, more frequently on the order of 40 to 50 per 1,000. Thus, initially, it appears that the Asian rural economy supports about double the nonfarm activity found in East, Central and Southern Africa.

\section{Female Participation}

Women account for a substantial proportion of both management and employment in African rural nonfarm enterprises. In rural Zambia, they own 60 percent of the nonfarm enterprises (Milimo and Fisseha, 1985), while their share in nonfarm employment ranges between 25 and 54 percent in countries such as Benin, Chana, Kerya, Nigerla and Zambia (Dahomey, 1964; Steel, 1977; Freeman and Norcliffe, 1985; Mueller and Zevering, 1970; Milimo and Fisseha, 1985).

Soclal and religious norms vary considerably among countries and In some cases tightly shape the economic options available to women. This is clearly the case in Islamic countries, as the Chad data in Table 1 Indicate. Even in non-Islamic countries, convention frequently dictates that women participate in activities that can be done in the home, with low 
capital requirements, and with akills they already have. This loads to their predominance in food preparacion, food services, basket making, and In some regions, ceramics, reaving and talloring. Acrose West Africa, and In many other reglons as well, wonen also play a najor role in retailing and trade. Because child-rearing, differential accese to education, and other social e.pectations restrict female participation rates in formal sector employment, women participate much more actively in informal activities. In Ghana and Kenya, for example, women's share of formal sector employment reaches only 10 and 14 percent, respectively, compared to 54 and 25 percent shares in Informal, small enterprises (Stee1, 1977; ILO, 1972).

\section{v. STRUCTURAL TRANSFORMATION OP THE RURAL ROMTARH ECOLOMT}

\section{A. Megatrends 4!}

In evaluating the present structure of Afrlca's rural nonfarm enterprises, as well as the potential for farm-nonfarm growth linkages, it Is useful to step back and review the grand lines of the economic transformation that has been taking place over many centuries in the African countryside. Begin long ago, with a countryside populated by selfsufficient, primarily agricultural households. No market exchanges take place, but within each household family members engage in both farm and nonfarm activitias. By flat, the head of household allocates labor and capital among activities and commodities among consuners.

Specialization emerges very early on in response to differing resource endowments and skills, technical change, opportunities for trade with outside regions, introduction of new crops, population growth and a host of other factors. Increased agricultural productivity per worker and the shift of employment out of agriculture are key features of that specialization, which is fundamental to economic growth. With improved 
farm productivity, households can begin to concentrate on selected activities beyond their own subsistence needs. As specialization becomes posalble, commodity and resource exchanges develop among houscholds, and the share of consumption from own production declines.

Initially, social protocols regulate exchanges among households. Fanilles transfer capital through roturing credit socletles (Bauman, 1977; DeLancey 1978; Miracle, Miracle and Cohen, 1980). They exchange labor through reciprocal cooperative wook parties (Erasmus, 1956; Moore, 1975) and comodities through ethnic rpecialization (Dahomey, 1964 and H1II, 1977) or reciprocal giv'

Eventually markets develop--1abor markets, rural financial markets and comodity markets. They operate alongside social allocation mechanisms and ultimately supplant them, but the tims frame is very long. Even today across rural Africa, only about 20 percent of all labor flows pass through labor markets, Including no more than five percent channeled through reciprocal work parties. 5/ The remaining 80 percent is allocated within familles by household heads. Capital flows likewlse remain predominantly intra-family, available evidence from rural nonfarm enterprises suggesting that today only in the order of ten percent of capital flows pass through formal financial markets. ㅇ

As specialization continues, nonfarm activity increases its relative importance in the rural economy; some nonfarm enterprises split off from the farm household, giving rise to full-time nonfarm households. Bvidence from Kenya suggests that transport, financial services and metal working are among the first activities to split off from the farm household, while weaving and talloring, resource extraction and construction iemain integrated longer (Freeman and Norcliffe, 1985). The growing proportion of nonfarm economic activity and the emergence of independent nonfarm enterprises go hand in hand with spatial 
concentration of population in village centers and rural towns. The concentration of people and activities generates a volwme of demand sufficlent to support specialized production units. Attesting to the Importance of this link, all available evidence indicates dramatically higher proportions of nonfarm activity in rural towns than in dispersed rural gettlenents (Table 5; Matlon, 1977; Lledholm and Chuta, 1976; Anderson and Leiserson, 1980; Haggblade; Hazel1 and Brown, 1987). Growth of rural towns and the consequent physical separation of farm and nonfarm activities accelerates the move to market exchanges of both inputs and outputs. In part, the difficulties of rural commications and transport prevent household heads from exerting control over input allocation and production decleions across distances. In addition, because they are specialized, nonfarm households must sell their wares to purchase food and other necessities. Today, avałlable evidence shows a surpriaingly consistent 60 percent cash share in total rural transactions in Africa (Coll1er, Radwan and Wangwe, 1986; Ghal and Radwan, 1983b; ILO, 1982a, 1982e, 1983 and 1985d; Cote d'Ivolre, 1967; King and Byerlee, 1977; Malawi, 1984; Massell and Parnes, 1969; and Oates, 1984). However, disaggregation reveals substantial differences between the rates of monetization of agricultural and nonagricultural commodities. Nonfarm entrepreneurs exchange the overwhelming majority of their goods and services for cash, while, continent wide, farmers sell only about 30 percent of all foodcrop production (FAO, 1986; Ancey, 1974; Cleave, 1974; Leunquin, 1960; Srivastava and Livingstone, 1983; Norman, Pryor and Gibb, 1979; Delgado, 1979; Hedlund and Landah1, 1983; Wilcock and Chuta, 1982; Anthony, et al., 1979). Although farmers market the bulk of their cash crops, these typically account for a small share of total farm production.

In some cases, rural nonfarm activities do not develop fron the specialization of polyvalent rural households but instead are implanted by 
outeiders. In fact, outsiders--Aslans In East Africa, Lebanese and Greeks In West Africa, and white settlere in East and Southern Africa--have Instigated much of the growth In African rural nonfarm activities. The source of growth in rural nonfarm activity--organic or implanted from outside--has strong implications for both the size structure and technology used in rural nonfarm enterprises.

As economies become more integrated, rural nonfarm enterprises must face competition from the outside, either from enterprises in growing nearby rural towns or from urban or imported goods. Manufacturers, especially those producing easily transportable items, face the stiffest competition. Yet rural services remain insulated; by their nature they are difficult to move across space. In the absence of intervention, the competitiveness of local enterprises and their raw material suppliers will determine the magnitude and composition of rural nonfarm enterprises.

When examining the pattern of rural economic development, it is essential to recognize the impact of resource endowments, location, population density, and income levels. These affect not only the composition and prevalence of rural nonfarm activity, but also the rate and nature of the transformation that takes place.

\section{B. Changes by size of Locality}

Consistent with this view of structural transformation, the data in Table 5 document the increasing Importance of nonfarm activities in rural towns and urban centers. Among nonfarm activities, commercial and service employment Increases most rapidly with size of locality. Moving from dispersed rural settlements to rural towns, commerclal and service employment densities frequently grow by multiples of 5 and 10 . Although manufacturing densities also rise, they more commonly grow by a factor of 2 or 3. 
Within sectors--especially within manufacturing--sone activition fare better than others. Data fron Zambia and Sierra Laone Indicate that artisanal activities such as spinning, weaving and pottery decline dramatically in importance with increasing locality size, undoubtedly the victims of competition from lower-priced manufactured substitutes. At the other extreme, trading, restaurants, food preparation, and repair work flourish as town size increases. II

C. Effect of Distance from Urban Centerg

Evidence from Ivory Coast identifies the types of rural nonfarm activities which are most likely to be bulldozed by competition fron urban and imported manufacturers. Table 6 indicates that basket making and weaving diminish precipitously ,in importance with proximity to major urban centers. Pottery also declines, although to a lesser extent. Because these activities constitute the three largest rural industries in Bouake Region, it is not surprising that manufacturing in the aggregate may fare less well than commerce and services as rural structural transformation proceeds. Certainly it is necessary to distinguish between declining industries--such as pottery, weaving, basket making, mat making and wood carving--and ascendant manufacturing activities such as food processing and, to a lesser extent, tailoring, carpentry and metalwork.

D. Chanres Over Time

Time series data tracing changes in Africa's rural nonfarm employment are 1imited and fragile. Using aggregate labor force data for. major subregions of the world, both Anderson and Leiserson (1980) and ILO (1979) make cautious judgements about long-term trends in rural nonfarm employment. They conclude that, over the past 20 years, total rural employment has been growing more rapldiy than agricultural employment in all regions of the world, including Africa. Therefore, they reason, the share of nonfarm activities in total rural employment has been growing as 
we11. Although both seta of authors acknowledge the frailty of the underlying data, their conclusions are consistent with the view of a rural structural transformation involving increasing specialization and diversification out of agriculture.

For Individual countries, time series data on trends in rural nonfarm employment are avallable only for slerra Loone and Rwanda. II The Slerrf Leone data are based on rigorous surveys of Identical areas and firms, first in 1974 and subsequently in 1980 (Chuta and Liedholm, 1982 ). Unfortunately, sanple sizes in the 1980 follow-up survey were not sufficiently large to permit inferences on trends in the most dispersed rural settlements, those below 2,000 in population. Nor do they include data for comercial, non-repair service firms, or for any enterprise employing over 50 workers. In practice the firm size cutoff should not pose a problen of incomplete coverage except in Freetown, which falls in the size category of cities over 250,000 .

The results fron Slerra Loone, displayed in Table 7, lead to several important conclusions. First, they indicate that repair services and food processing have grown most rapidly, both overall and in small and medium rural towns. Second, while manufacturing in general appears to have declined in the smallest localities $(2,000-20,000$ persons), tailoring and welding have held constant, and they, along with carpentry, have grown very rapidly in the medium sized towns $(20,000-250,000)$, These observations are consistent with the previously cited spatial evidence suggesting that repair services and food processing grow most rapidly with the development of rural towns.

The Rwarda time series data (Vanvali, 1985), tracing changes in rural nonfarm employment between 1978 and 1983, are more conjectural than those from Sierra Leone, since they splice together two very different data sets, the 1978 population census and the results of a more recent: 
agricultural census. Nevertheless; chey once again point to service, comerce and restaurants as the fastest growing nonfarw sectors. While overall manufacturing grew more slowly than services and comerce, the Rwanda data, like those from Slerra Leone, do polnt to woodworking, metal work and textiles as anong most buoyant rural Industrial activities. B. Correlates of Growth in the Rural Nonfam Economy

We hypothesize that several factors affect the growth of the rural nonfarm econony.

1. Development of rural towns. In part this way be due to the benefits of economies of scale as well as the prospects for centralized, cost-effective provision of key infrastructure and services.

2. Level of infrastructure. Decreases in the cost of information and transport flows improve the efficiency with which rural labor and financial markets channel inputs into activities yielding the highest returns. Moreover, decreased transport costs open up rural resources and narkets to viable exploitation, facilitating movement to a more speclalized, productive rural economy.

3. Per capita income. Engel's Law mandates this tandem movenent for the overall economy, and if definitions of "rural" remain Iiberal enough to encompass the nonfarm growth in rural towns, Increases in income will lead to an Increase in the nonfarm share of total rural income. 
4. Arricultural Income per capita. Increased farm productivity is normally a precondition for rural specialization if labor is to be released to nonagricultural pursuits without lowering food production. Also, if rural growth multipliers exist, both the production and consumption linkages entrained by agricultural growth will stimulate the rural production of nonfarm goods and services.

5. Population density. Higher density makes possible more rapid attainment of minimum efficient scales for full-time speciallzation, and the emergence of a service sector depends on close physical proximity between purveyors and clients. Moreover, high population density may limit the number of households able to survive from agriculture alone, thus forcing some into nonfarm activities as income supplements.

Empirical evidence presented in the preceding sections has provided strong support for Hypothesis 1 concerning the importance of rural towns in the development of rural nonfarm enterprises. Table 7 furnishes particularly persuasive documentation. While data that would permit testing of Hypothesis 2 ere not readily available, anecdotal evidence from Kenya and Ghana does stress the key role of ruial towns and their infrastructure in the development of nonfarm enterprises (Kreamer, 1986; Child, 1976; ILO, 1985a).

We have assembled a sufficient number of cross section observations to permit at least a crude initial attempt at exploring the third, fourth and fifth hypothesized correlates of rural nonfarm activity--per capita income, agricultural income per person, and population density. The plots in Figures 1, 2 and 3 display these relationships for the 12 African 
and 4 Asian countries for which comparable data are available. The 12 African countries include all those on Table 3 except Zimbabwe and Mozambique, for which it was not possible to break out employment in rural towns, and Ivory Coast where data from only one region was avallable. We have plotted nonfarm employment percentages rather than densities, because In cases such as these, where complete rural employment data are avallable, percentages are less susceptible than are densities to noise introduced through differences in working age classifications and measured female participation rites. The raw data come fron the same sources reported in Table 3 adjusted to include rural towns up to 250,000 in size.

Figures 1 and 2 depict a positive relationship between rural nonfarm employment and both per capita GNP and agricultural income, thus supporting Hypotheses 3 and 4 . Correlation coefficients for the African countries portrayed stand at .41 and .33 , respectively. Extending the range of observation, the Asian data reinforce both of these conclusions. In addition, Figure 2 indicates that, for any given level of agricultural Income, Asian countries generate higher levels of nonfarm employment than do their African counterparts, thus suggesting that agricultural multipliers may be higher in Asia.

Only in testing the effect of population density do the African cross-section data appear ambiguous. Except for Rwanda, the outlier in the lower right, the African data Imply essentially no correlation between population density and rural nonfarm employment. Yet extrapolation to population density levels common In Asian countries does suggest a positive relationship. Perhaps 50-100 people per square kilometer represents a threshold level necessary for population density to play a discernible role in stimulating rural nonfarm activity. Lending credence to this notion, the Nigerian data in Figure 4 indicate a strong .87 correlation between population density and adult rural nonfarm employment (.78 for children) in 
a heavily populated African setting. Including data from dietricts across one Nigerian state, Figure 4 avoids the difficulties inherent in crosssection comparisons of countries with varying resource endowments, labor force defint tions and policy environments.

VI. MAGNITUDE OF THE GARY-NOLEARY IINTAGES

As a prerequisite for estimating the wagnitude of agricultural growth multipl lers, as well as an ald in gaining a fuller understanding of the nature of farm-nonfarm linkages, it is useful to examine in sone detail avallable evidence on the strength of intersectoral linkages in rural Africa. Five different 1inkages are important, two in factor markets and three in product markets. The factor market linkages involve capital and labor flows betweer, agriculture and nonfarm enterprises. Product markets Include backward production linkages from agriculture to rural input suppliers, forward production linkages from agriculture to processors and distributors, and consumer demand linkages generated as a result of increasing farm incomes.

\section{A. Gapital Flows}

Most observers belleve the outflow of capital from agriculture to be larger than the reverse flow from nonfarm activity to agriculture. Certainly at an aggregate level, a large accumulation of evidence suggests that surpluses have been consistently transioerred out of agriculture through fiscal, crop pricing and trade policies (World Bank, 1981; Lee, 1983; ILO, 1982b; Sharpley, 1981). Marketing boards and export levies, for example, typically tax away 30 to 50 percent of farmers' cash crop prices (World Bank, 1981). Given the structure of government expenditures in most African countries, it is very likely that these agricultural surpluses have been transferred primarily to urban areas and into nonagricultural activities. Private investors have also channelled investment funds from 
agriculture to nonfarm activities (Freaman and Norcllffe, 1985; Okelo, 1973; and WIIllams and McClintock, 1981). Evidence from Kenya and sierra Leone suggests that agricultural surpluses account for between 15 and 40 percent of nonfarm investment funds (Ch11d, 1977; Liedholm and Chuta 1976). Surpluses generated in nonfarm ectivitles likewise furnish funds for productivity enhancing investments in agriculture. Kitching (1977), in a review of sixteen farm management surveys from East Africa, finds repeated evidence of nonfarm earnings playing a crucial role in farmer acquisition of productive agricultural assets, especially land. The positive impact of off-farm earnings on agricultural investment has also been observed in Kenya (Collier and Lal, 1986; Haugerud, 1984), Milawl (Cleave, 1974), N1gerla (Berry, 1975) Tanzania (Cleave, 1971) and Uganda (Massel and Parnes, 1969).

\section{B. Labor Flows}

Nonfarm labor usage moves contracyclically to demands of the agricultural calendar resulting in substantial seasonal labor flow between the rural farm and nonfarm sectors. We estimate that 20 to 40 percent of the rural labor force works in both farm and nonfarm activities, this range representing the sizeable magnitude of the labor flows moving back and forth between the rural farm and nonfarm sectors. 101

\section{Backiard Linkages from Agriculture to Bural Input Suppliers}

Rural enterprises can supply some of the agricultural inputs required by farmers. For example, seasonal data from Sierra leone indicate that blacksmithing activity reaches its peak during the height of the agricultural season because of the demand for repair services (Liedholn and Chuta, 1976). Of course, the type and magnitude of backward 1inkages varies depending on agricultural technology, size of holding, type of crop, and whether production is irrigated or rainfed. 
In general, the backward 1inkages in Africa appear to be weaker than those measured In Aala. Tn see why, recall that Johnston and Kilby (1975), In evaluating the magnitude of backward 1inkages in Asia, Identify fertilizer, followed by equipment and finally cement and building materials as the three key production inputs to agriculture. In Africa, probably only Nigeria, with its petroleum and large market can aspire to viable fertilizer production. Furthermore, topography and hydrology severely limit irrigation potential in Africa (Delgado, 1984) and therefore the demand for pumps and other Irrigation equipment, cement and building materials.

But the potential for production linkages lies not necessarily in today's technology, it lies rather in what will be required to generate the first round of future griculturally-propelled growth. It is increasingly clear that peak season labor bottlenecks constrain output in most areas, so some form of biological or mechanical solution w11l have to address that problem (Elcher and Baker, 1982; Mellor, Delgado and Blackie, 1987). If the most economic solutions turn out to be mechanical, backward nonfarm linkage multipliers may grow. The multipliers computed below use a range of estimates of equipment Inputs to generate a sense of the magnitude of the growth linkages that can be reasonably expected from this quarter. D. Forward Linkages from Agriculture to Processors and Distributors

Table 8 attempts to break out from total rural nonfarm employment only activities related to agriculture, either supplying inputs or processing outputs. Because many firms service a multiplicity of clients, this is not possible to do with great precision, although three tentative conclusions do emerge. First, backward linkages appear far smaller than the forward processing linkages from agriculture. Even if all metal working, blacksmithing and metal repair were related to agriculture, the 
forward processing and distribution links would be at least double the backward Iinkages in Kenya and over 15 times as great in Zambia.

Second, food processing clearly achleves prominent stature among forward linkages. Although bread baking requires imported wheat flour, virtually all other processing activities involve transformation of local agricultural production. Furthermore, oil extraction, sugar production, tes drying and packaging, coffee and cocos dehulling and drying are often performed in rural areas by large scale enterprises. While we know these large scale activities take place predominantly in rural areas, the small scale orientation of much of the past research causes those activities to elude the statistical net. Hence even the substantial figures in Table 8 understate the magnitude of rural agroprocessing.

Finslly, distribution of agricultural products generates, after food processing, the second largest of the forward linkages from agriculture. If retailing of local agricultural produce is approximately proportional to the share of marketed farm production in total rural consumer cash expenditure, then about 50 percent of rural retailing represents a forward distribution link from agriculture. 11/ Applying this proportion to data from Zambla, Table 8 indicates that distribution furnishes between 15 and 50 percent of total agricultural 11nkages, the higher proportion prevailing in rural towns.

\section{E. Consumption Links}

As per capita farm incomes rise, the demand for local services, housing, durables, and higher quality foods typically increases more rapidly than the demand for foodgrains. The Aslan experience suggests that the production of these commodities and services is labor intensive, hence rural employment in the non-foodgrain sector increases quite rapidly with per capita farm incomes (Me1lor, 1976; Gibb, 1974; Bell, Hazell and Slade, 1982). Bict these patterns of growth may depend on a combination of high 
population density and adequate transport facilities to make rural services accessible to the villages and so may be less applicable to large parts of Sub-Saharan Africa. We hypothesize that the absence of relatively cheap, labor-intensive goods and services in rural areas will result in a slower shift of demand from foods to services in Sub-Saharan Africa than in Asia, with consequent weaker demand linkages to the rural nonfarm economy.

Of the few household expenditure studies which allow assessment of African rural consumption linkages, the most comparable were undertaken for farm households in Gusau, Northern Nigeria (Hazell and Roell, 1983), rural households in Sierra Leone (KIng and Byerlee, 1977), and households in three villages in Zaria Province, Northern Nigeria (Simmons, 1976b). These are sumarized in Table 9 together with comparable results for farn households from two ssian studies: the Muda region of Malaysia (Hazell and Roe11, 1983) and North Arcot district, South India (Hazell and Ramasamy, forthcouing).

As the data in Table 9 Indicate, African spending patterns support far 1 ess rural nonfarm activity than do those in Asla. Average expenditure on rurally produced nonfoods averages about 18 percent in Muda and North Arcot, double the roughly nine percent prevalling in Gusau and sierra Leone. And with the marginal budget shares, crucial predictors of the IInkages to be anticlpated from growing Incomes, the gap widens. African consumers in Gusau and Sierra Leone spend only 11 to 12 percent of Incremental income on rurally-produced nonfoods, while the comparable Asian figures from Vuda and Gusau stand at 31 to 26 percent, triple those in Africa. In part, this difference arises because African consumers spend far more of their average and marginal income on rurally-produced foods. While total rural consumption 11 inkages (on foods plus non-foods) are approximately equal in the cases reviewed, the Asla data Indicate greater diversity into nonfoods. 
Transportation notworks and proxinity to rural town appeara to contribute to the much highor Amian incromental consumption on rurallyproduced goods and services. A comparison of the African consumption studies reveals that householis in Zaria Region, Nigerla spend a significantly greater portion of their income on nonfoods, especially services, than do consumers in Sierra Loone and in Gusau. Th1s difference arises, at least in part, because simmons (1976b) deliberately selected her three Zaria study villages for their proximity to tha urban center of zarla. Consequently consumere in the etudy villages had easy access to a wider range of consumer goods and services than are avallable in nost rural African villages. Contrasting the Guan and Muda studies rainforces this conclusion. In Muda, with its dense population and axcellent tranaportation systen, consumers apend larger income increments on rurally-produced nonfarm goods and services than do households in Gusau whore villages are typically much more removed from market centers and are faced with very limited means of transport.

The Slerra Leone study (King and Byerlee, 1977 and 1978) also supports two themes that emerged from the time-series and locallty-size employment data. First, it indicates that consumption Iinkages are much stronger for rural services than for rurally-manufactured goods. Marginal budget shares for rural services stand at 11.2 percent whlle those for rurally-manufactured goods reach only 1.1 percent. Second, KIng and Byerlee's results underline the importance of rural towns. Their data Indicate that consumers allocate 5.5 percent or Incremental expenditure on goods and services produced in rural towns, almost triple the rate of spending on products made In large urban sreas.

\section{F. Caution}

The avallable evidence examined thus far has auggested that African farm-nonfarm linkages may be lower than those found in Asia. 
However, it is Important to bear in mind that avallable measures may bias the African rural Iinkage estimates downward because of a key feature of the African ruxal econony--the high share of nonmarketed goods and services In total consumption. Because they are not marketed, many rural African goods and services are not measured. The Gusau consumption study, for example, does not impute a value for consumption of home produced nonfood commodities. And none of the studies values nontraded household services.cooking, cleaning, laundry and child care. Furthermore, major agricultural Improvements take the form of labor time invested in tree crop planting, land clearing, leveling or ridging. A recent study in Nigeria estimated that 80 percent of total agricultural investment took this form, while only the remaining 20 percent represented cash expenditure on equipment (Adesimi, 1983). Performed primarily with unremunerated family workers, labor-based investments are normally excluded from calculations of the value of agricultural investment. Because the Aslan economies are more highly monetized, more of these services enter the measured consumption accounts. Thus, in the same way GNP comparisons exaggerate income gaps between rich and poor countries--because the development of labor markets monetize what were previously intra-household labor flows and because high female workforce participation leads to booming restaurant, laundry, house cleaning and childcare businesses--the Asia-Africa comparisons are likely to overstate the apparent linkage gap between the two reglons. The differences may well diminish in the future as rural Africa becomes increasingly monetized.

\section{PROBABIE MAGNITUDE OF THE AGRICULTURAL GROWTH WULTIFLIERS}

\section{A. Direct Gross-Regional Estimation}

Available regional data from Togo and Sierra Leone (ILO, 1982d, Matlon et a1., 1979), enable us to relate regional differences in rural 
nonfarm earninge to differences in agricultural incone. These data reproduced and plotted in Haggblade, Hazell and Brown (1987), show a clear positive relationship between per capita agricultural incone and per capita rural nonfarm earnings, reinforcing results from our earlier cross-country analysis reported in Figures 1-3.

By regressing rural nonfarm Income on agricultural earnings, we can use these data to generate crude estimates of the agricultural growth multipliers. Equations (1) and (2) display the results of two ordinary least square regressions of per caplta nonfarm income (RNFY) on per capita farm income (AGY). The figures in parentheses are standard errors. Note that the Sierra Leone regression includes all regions except Scarcies, which is an atypical rural region, one with a high proportion of fishing income which is clearly unrelated to agriculture.
(1) Togo
RNFY $=5.8+.43 A G Y$
$R^{2}=.56$
(2) Sierra Leone
RNFY $=4.2+.14 A G Y$
$R^{2}-.31$

$$
\text { (.09) }
$$

It would be improper to Infer strict causality from these relationships, because there may be other exogenous sources of growth in rural nonfarm income. Yet given the overwhelmingly agricultural character of rural Togo, the results in equation (1) suggest that in rural Togo a \$1 increase in agricultural income leads to a $\$ .43$ increase in regional nonfarm earnings. But the Slerra Leone estimate, even after removing the outlier region, is far lower. It implies that a $\$ 1$ increase in farm income generates only an additional $\$ .14$ in nonfarm earnings. Closer inspection of the survey methodology reveals the reason for this low figure. The Sierra Leone data exclude income from households primarily engaged in trad- 
Ing. Because comuerce generates consistently the highest share of African rural nonfarm incone, the Sierra Loone data likely seriously underestinate total rural nonfarm earnings. For present purposes, one advantage of this onisaton is that it reduces the coverage of the nonfarm multiplier to principally production linkages. Supporting the notions advanced previously, this interpretation suggests that rural production ilnkages from agriculture are in fact very low, at least in the predominantly hand hoe agriculture of Sierra Leone.

\section{B. Aodel of Regional Aoricultural Multiplfers}

In view of the limited opportunities for diruct estination of growth multipliers, much of what we can learn must cone fron modeling. Hazel1 (1984) has developed a particularly useful model that allows estimation of regional growth multipliers based on three basic paranetera, two production and one consumption. Values for each can be obtained from farm managenent, rural nonfarm enterprise, and consumption surveys. Although small, the model allows us to assess three Important features of farm-nonfarm 11nkages: (a) differences in African and Asian growth multipliers; (b) the Implications of alternative types of agricultural growth on the ensuing nonfarm 11nkages; and (c) breakdown of the total wultiplier into its production- and consumption-based components.

Described in detail in Hazell (1984) and in Haggblade, Hazell and Brown (1987), the model characterizes the supply structure of rural reglons as follows. 12/ The supply of their major tradable output--foodgrains or export crops--is typically fixed by technology and, in Asia by land, in Africa by labor. In contrast, output of nontradables--primarily rural services, but including some income-elastic agricultural products such as fruits, vegetables and meat, and sone rural manufactures--is elastic. Assuming the prices of all traded commodities are fixed outside the region, Hazell derives a model which estimates the Increase in regional value added 
thet would occur if, through developient of now technology or Investment in agriculture, governnent were able to relax the supply constraint liniting output of major agricultural tradables. Given one-unit increase in value added from the region's major tradable agricultural output, the model estimates the resulting total increase in regiona: value added as a function of three parameters: consumers' marginal budget share spent on nontradables, producers' demand for nontradable Intermediate Inpute as a ratio of gross reglonal output, and the ratio of value added to gross regional output.

Three studies have used Hazell's model to estimate the magnitude of agricultural growth 1inkages. Hazell (1984) has applied the model to estinate Asian growth multipliers, Rogers (1986), using data from Mauritania, has computed multipliers for Sahelian West Africa, and Haggblade, Hazell and Brown (1987) have used the model to compare growth multipliers in Africa and Asia as well as to contrast growth linkages resulting from alternative agricultural growth strategies.

Several important conclusions emerge from these modeling efforte. The first concern the accuracy of the model and the magnitude of Asian growth Iinkages. Hazell (1984) In his initial formulation, used the model to estimate regional agricultural growth multipliers for the Muda River Region of Malaysia, a moderately prosperous rice growing region that had been studied in great detail by Bell, Hazell and Slade (1982). The small, three-parameter model generated a regional agricultural growth multiplier of 1.82, Indicating that a $\$ 1$ increase in value added from tradable agricultural output would result in an additional $\$ 0.82$ increase in regional income. This result lies very close to the 1.83 value added multiplier reported by Bell, Hazell and Slade (1982) after a much more careful analysis, lending credibility to the smaller model's projection. A second detailed study, undertaken by Hazel1, Ramasamy and Rajagopalan 
(forthconing) In the North Arcot region of South India, also computes an agricultural growth multiplier of 1.83. In this case too, the small threeparameter model generated virtually identical results.

Applying the model to African agriculture, Rogers (1986) computes much lower multipliers. Using a sight variant of the Hazell model along with data from Mauritania, Rogers estimates agricultural growth multipliers under a range of conditions. Most estimates clump around 1.27. Civen the harsh rural economy of Mauritania, this estimate very likely paints an unduly pessimistic picture of agricultural growth multipliers throughout the rest of Sub-Saharan Africa.

Using what are probably more representative African data-consumption parameters from Slerra Leone and Nigeria along with production parameters from farm and nonfarm budget studies across the continent-Haggblade, Hazell and Brown (1987) estimate agricultural growth multipliers on the order of 1.5. This estimate places the African growth multipliers at about 60 percent of the magnitude of those estimated in Asia; a $\$ 1$ increase in value added from agricultural tradables produces an additional 0.50 of rural income in Africa compared to about $\$ 0.83$ in the Asian countries for which we have evidence. These Africa multipliers of about 1.5 are also strikingly close to the 1.43 direct cross-regional estimate reported earl:er for Togo (Section VII A).

The model can also shed light on potential differences in rural linkages generated by alternative agricultural growth strategies. Haggblade, Hazell and Brown (1987) use African farm management data to compare rural income multipliers 1ikely to emanate from small farmer growth strategies with strategies based on promotion of estate agriculture. Under a range of probable production parameters, the model predicts regional multipliers in the range of 1.45 and 1.55 for both small and large farmer strategies. The surprising similarity between estate and smallholder 
multipliers occurs because while large farmers are nore dependent on purchased inputs (as reflected in their lower value added to gross output ratios) and hence have potentially stronger links to the nonfarm economy, the potential does not materialize because many of those inputs are produced in urban areas or overseas. But this result assumes identical consumption patterns among small farmers and estateholders. If estate families are found to have more urbanized expenditure patterns--and unfortunately consumption data are simply unavailable indicating whether or not this is so--the estate-dominated reglons would generate regional growth multipliers of only about 1.31, substantially below those of smallholders. Finally, the model has been used to separate out the contribution of consumption and production linkages in overall regional multipliera (Haggblade, Hazell and Brown, 1987). Under conditions prevalling In SubSaharan Africa, that work indicates that consumption Iinkages account for about 80 percent of total agricultural growth multipliers. In Asia, on the other hand, the relative importance of consumption linkages appears much amaller. In the Muda region of Malaysia, consumption Iinkages account for about 60 percent of the total multiplier, while in North Arcot the consumption share drops to 50 percent (Be11, Hazell and Slade 1982; Hazell, Ramasamy and Rajagopalan, forthcoming). This does not arise because the consumption linkages are more powerful in Africa than in Asia; the marginal budget share for nontradables is smaller in Africa. Rather, the different relative importance of consumption and production in overall growth multipliers reflects the much weaker inter-industry linkages in Africa. The weak African production linkages likely stem, as discussed earlier, from the much lower level of mechanical input use In Africa along with the absence of important construction and maintenance associated with Asian Irrigated agriculture. Relterating inferences drawn from the Togo and Sierra Leone direct multiplier estimates above, the modeling efforts 
project weak African agricultural production Iinkages with the rest of the rural econony.

\section{Macroecononic Consequences and simulations}

The foregoing analysis presumes that regional growth is an and in Itself, and it gives no regard to spillover effects that might be induced elsewhere in the national economy. For example, Imports into a rural region are leakages as far as regional growth is concerned. But if these goods are produced in other rural areas, or if they create jobs for the urban poor, they will still be desirable from the national viewpoint. sinilarly, savings that are invested outside the region represent a 1088 to regional growth, but they are nevertheless valuable in furthering national econonic growth. Conversely, reglonal growth may incur costs elsewhere in the economy. For example, labor and capital will be less likely to move from rural to urban areas if rural regions are growing successfully, and this will act to dampen the growth of the urban economy.

To measure the full indirect Impact of agricultural growth in the national economy requires a general equilibrium modeling approach. Byerlee has undertaken such work for Nigeria (Byerlee, 1973) and Sierra Leone (Byerlee, et al., 1977). Using a macroeconomic simulation model, he analyzes the impact of government policles for expanding, alternatively. the production of export and food crops. For Nigeria, his results show that policies which expand food crop production increase value added in nonagriculture by Naira 0.23 for each Naira 1.00 Increase in value added in agriculture. 13/ In contrast, policles to increase export crop production lead to between 0.73 and 0.96 Naira of additional value added in nonagriculture for each Natra 1.00 increase in agricultural value added.

The results for Sierra Leone are more modest, probably reflecting the much weaker industrial base of that country. Increases in food crop production have a similar Impact on the national economy as in Nigeria: 
each Leone 1.00 of additional value added In agriculture generates Leone 0.29 of nonagricultural value added. But the linkages emanating from increased export crop production are weaker than in N1geria--Leone 0.42 of value added in nonagriculture for each Leone 1.00 of additional value added in agriculture.

These results are generally consistent with the size of our regional multipliers. This would seem to suggest that any positive spillover effects arising beyond a region's boundaries are largely offset by negative spillover effects.

There are no directly comparable studies for Asia, but modeling studies of India (Rangarajan, 1982) and South Korea (Adelman, 1984) suggest stronger Iinkage effects from agricultural growth on the national economy than in Sub-Saharan Africa.

\section{CONCLUSIONS}

\section{A. Implications for Policy}

Several themes have recurred throughout this review. Together, they point in clear directions for policy makers and practitioners interested in balanced rural growth and in maximizing the rural nonfarm spinoffs of agricultural progress.

- Agricultural growth will be essential in launching successive rounds of growth in rural areas. Consumption Iinkages appear particularly important. Raising frrm labor productivity is therefore important, not only because it permits the release of labor from agriculture to nonagricultural pursuits, but because it boosts per capita income to levels that enable consumer diversification from food into nonfood items.

- Government policies affect not only the magnitude of agricultural growth but also the ability of rural nonfarm enterprises to respond to the increased demand. Investment codes and related legislation which have 
discriminated against small, rural nonfarm firms (Haggblade, Lledholm and Mead, 1986; Page, 1979; World Bank, 1982, 1987), together with hisi:oric urban policy blases (World Bank 1981), w111 need to be redressed if rural nonfarm enterprises are to achieve their potential for income generation and economic decentralization.

The historical focus on manufacturing, by both policy makers and researchers (Haggblade, Hazell and Brown, 1987) seems now worthy of redirection. Spatial, time series and consumption data uniformly point, not to manufacturing, but rather to commerce and services as key growth sectors over the course of Africa's rural structural transformation. Services, in particular, are the activities best insulated Srom urban competition; hence consumption leakages are smallest in this sector. Service and commercial enterprise should not be excluded from assistance programs as has frequently been the practice in the past.

Rural towns emerge as focal points in the development of the rural nonfarm economy. Cross-section data systematically identify much higher densities of nonfarm activity in rural towns than in dispersed rural settlements. By providing nonfarm enterprises with larger markets, rural towns offer firms the potential to exploit economies of scale. Prospects for sharing equipment as well as the emergence of repair and support facilities induce enterprise establishment in rural towns. Moreover, the emergence of rural towns enables policy makers to provide necessary productive infrastructure at lower cost than would be possible under widely dispersed settlement patterns.

- For rural towns to play their role in a balanced rural development process, it will be essential to assure adequate economic and social infrastructure to support nascent modern nonfarm activities. Physical infrastructure will undoubtedly play a key role. Anecdotal evidence on the rise of secondary cities in developing countries identifies ground 
transportation--roads or rallroads--as necessary first infrastructural Investments (Rondinell1 and Ruddle, 1978; Rondinelli, 1983). The consumption data from Africa and Asia relnforce this notion, highlighting the Importance of road access to rural towns in stimulating agricultural consumption 1inkages. Beyond that, the spotty record of rural electrification programs alone in fostering industrialization (Fluitman, 1983; Okelo, 1973) suggests a need to review evidence on complementarities, sequencing and necessary additional conditions for generating productive impact fr: $n$ infrastructural investments. Institutional infrastructure will also be essential in fostering the transition to a more specialized, productive rural economy. Efficient rural financial markets will be particularly important. It appears that improvements on this front will require integration of the existing informal credit markets with the formal banking system. Labor markets are also essential, and their increased efficiency will follow in the wake of improved communication and transport infrastructure.

Because much current writing emphasizes the need for investments In infrastructure, policy makers can all too easily overlook the collateral need for investments in people. Since services will be among the most rapidly growing rural nonfarm aptivities, investment in human capital will likely be essential for realizing those potential gains. Services depend more on skilled people than on equipment and infrastructure.

Many programs of direct assistance to rural nonfarm enterprises, although by no means all, have been cost effective. 14 I the record of technical assistance and projects providing modern workshop facilities have been most checkered; two-thirds of 17 recent project evaluations have found benefit/cost (B/C) ratios below one (Haggblade, 1982; Kilby, 1979). On the other hand, credit projects, especially those supplying working capital, have enjoyed greater success. A recent evaluation of seven small 
enterprise credit projects found that all have B/C ratios in excess of one (KInly and d'Zmura, 1985). Overall it appears, as Kilby (1979) originally suggested and subsequent appraisals have confirmed, that programs which aim to provide o complete package of financial, technical and management assistance--nursery industrial estates, for example--are generally less effective than programs that identify and provide a single aissing ingredient necessary for enterprise success.

- Women dominate many of the nonfarm activities that will grow most rapidly during structural transformation--activities such as food processing and preparation, talloring, trading and many services. They likewise hold major interest in many of the declining rural nonfarm occupations--basket making, mat making, ceramics and weaving. Consequently, women will be key actors in the economic transition of Africa's rural economy. 15/ To facilitate their contribution to an accelerated rural transformation will require assistance agencles and governments explicitly recognizing the key role to be played by women.

\section{B. Implications for Research}

This review, in sorting through the dellcate and spotty available evidence, has identified several key priorities for future research.

- To improve our confidence in estimates of growth multipliers, the key parameters to be measured are the marginal budget shares and expenaiture elasticities for rurally-produced nontradables. Those who analyze, and especially those who collect, rural consumption data can perform a vital service by tagging and highlighting the locational features of rural consumption decisions.

On the supply side of the rural nonfarm economy, it will be particularly important to start filling in descriptive and analytical profiles of the service and commercial sectors of the rural economy as a complement to the Important, detalled work already undertaken on rural manufacturing 
and repair. Research in the future should also include both large and sma11, formal and informal firme within its purviow. Subsector research offers is a promising means of doing this (Boomgard et al., 1986). By looking at key final product markets one at a time and reviewing the entire network of resource flows from vaw materials to consumer, the subsector approach integrates analysis of the relevant manufacturing, comercial and service segmente of the economy. And by including large and small firms together, it provides useful indications of their competitive or complenentary relationships in alternative channels thereby providing Insights into future dynamics in each commodity subsysten.

- Finally, we need a detalled review of the links between rural Infrastructure and the stimulation of rural nonfarm activity. Questions of sequencing, complementarities, substitutability, necessary collateral inputs, and effective methods of financing and maintenance remain obscured. C. Mantitude of Multipliers

Based on the limited evidence avallable to date, we estimate Africa's rural agricultural growth multipliers to be in the order of 1.5 . That is, a $\$ 1$ increase in agricultural incomes will generate about 50 cents of additional rural income, primarily among suppliers of rural nonfarm goods and services. This initial estimate places the African multipliers at about 60 percent of what they appear to be in a few Asian countries for which we have estimates.

Different types of agricultural growth--smallholder as opposed to estates, cash as opposed to food crops, trae crops as opposed annuals, mechanized as opposed to animal traction or hand hoe agriculture--may generate different multipliers. But initial estimates, based on simple modeling calculations, suggest surprisingly little variation. Contrasting small farmers and estates, and tree crops as opposed to annuals, we have found that the multipliers vary little within the range tested. We must 
caution that farm management and aspecially consumption proflles of the very wealthiest farms remain elusive. As data from these very high Income farmers become avallable, the range of agricultural growth multipliers may well widen. But it remains to be seen whether presumably lower rural consumption linkages will be offset by potentially greater production links.

We hypothesize that African multipliers are lower than those found In Asia because of a combination of different policies and different natural environments. The nature of African rainfall patterns arid geology of river basins preclude cost effective irrigation on a scale as large as In Asia. Hence backward linkages into pump supply, canal construction and maintenance, all currently important in Asian countries, will simply be unavailable in Africa. Population density also remains much lower in Africa, requiring larger geographic market areas than in Asia to support minimum viable scales of business activity. This diminishes the competitiveness of rural nonfarm producers contesting markets with large urban suppliers. In addition, African consumption patterns seem less diversified into nonfoods than in Asia. But at this stage it is not possible to say whether these differences arise from different income levels, differing preferences for urban and imported goods, measurement error stemming from the large share of normonetized goods and service transfers in Africa, or simply result from an array of existing fiscal, trade and pricing policies which couple with lower levels of productive infrastructure to Induce lower second-round supply responses in rural Africa. We have much still to learn. 
1 We would like to thank Dennis Anderson, Arthur Gibb, Peter Kilby, Carl Liedholm and Vijay Vyas for helpful comments on an earlier draft. We are likewise grateful to Yacob Fisseha and Chris Windheuser for help in locating elusive data and to Kwesi Amissah and Nandinee Kutty for research assistance. The views expressed herein are the authors' and should not be attributed to the World Bank or its affiliated organizations.

2) See, among others, Kilby, 1962; Liedholm, 1973; Liedholm and Chuta, 1976; Stee1, 1977; Chuta and Liedholm, 1979; Page, 1573; Anderson and Leiserson, 1980; Page and Steel, 1984; Liedholin and Mead, 1986; Kilby and Lledholm, 1986; Milimo and Fisseha, 1986; Lledholm and Mead, 1987.

3/ Definitional differences may account for some of the apparent variation in rural nonfarm employment across countries. Individual country definitions of rural, age of economic participation and female participation rates follow:

Benin:

Cameroon:

Chad:

Ghana:

Ivory Coast, Bouake Region:

Malawi:
Rural - not explicitly defined. Implicitly inc?.udes population in localities of less than 9,500 persons. Fconomically active - all people over 15 years of age. Women's participation rate - 73 percent versus 95 percent for men.

Rural. - all areas outside of provincial, departmental, arrondissement and district headquarters and outside selected settlements over 5,000 with high schools, hospitals or traln stations. Economically active population 6 and over. Women's participation - 38 percent versus 62 percent for men.

Rural - all population living outside of prefecture headquarters or in localities of less than 5,000 in the South and less than 3,000 in the North. Economically active - all people over 15 years of age. Women's participation rate $=28$ percent versus 94 percent for men.

Rural = localities under 5,000 according to official definition. But economic activity breakdown only available for towns under 10,000. Data in table refer to towns under 10,000 as rural. Economically active all people over 15 years of age. Women's participation rate - not given explicitly but is evidently 33 percent lower than men's.

Rural - entire Bouake region including rural towns. Economically active - population aged 15-59. Women's participation rate - not specified.

Rural - undefined. Rural towns taken as all urban areas outside of Lilongwe, Blantyre and Zomba. Economically active - all persons over 10 years of age. Women's 
Mal1:

Mauritania:

Mozambique :

Rwanda:

Senegel:

Sierra

Leone:

Tanzania:

Togo:

Zimbabwe: participation rate -44 percent versus 52 percent for men.

Rural - areas outside of legally designated "communes". Implicitly settlements over 3,000. Economically active - not defined. Women's participation rate - not given.

Rural - not defined. Taken as all regions except three except with over 85 percent population designated as urban. Essentlally all localities under 10,000. Economically active - all persons over 12 years of age. Women's participation rate - 25 percent versus 82 percent for men.

Rural - all areas outside 12 major cities. Twelve city sizes not cited. Economically active - all persons over 12 years of age. Women's participation rate -81 percent versus 78 percent for men.

Rural - areas outside perfecture headquarters and two other localities designated as urban. Economically active - all persons over seven years of age. Women's participation rate - not given.

Rural - localities less than 1,000. Economically active - all persons over six years of age. Women's participation rate -23 percent versus 60 percent for men.

Rural - census definition, all towns under 5,000. Since employment not broken down by town, rural defined here as all districts with at least 75 percent of their population in localities of under 2,000. Bconomically active - all persons over 12 years of age. Women's participation rate - equal to that of men. Each accounts for 50 percent of labor force.

Rural - regional and district headquarters plus towns over 5,000. Economically active all persons over five years of age. Women's participation rate $=55$ percent versus 54 percent for men.

Rural - all areas outside Lome and six legally designated "communes". Economically active - population over 12 years of age. Women's participation rate - not given.

Rural - population living in towns under 2,500. During 1969 census urban - any locality over 150 if majority of males employed in non-agricultural occupations. Econumically active - population over 15. Women's participation rate -48 percent versus 80 percent for men. 
Ind1e:

South Kores:

Talwan:

Thalland:
Rural - localities with population 5,000 or 1 ess. Econonically active - no age cutoff; apparently includes workers of all ages who worked the major part of the previous year. Women's participation - 15 percent versus 51 percent for men. Unlike other countries, this is calculated as a percentage of total rather than working age population.

Rural - unincorporated rural areas (myeons). Implicitly includes settlements under 20,000. Economically active - all persons over 14. Women's participation rate - 33 percent versus 79 percent for men.

Rural = undefined. Breakdown here follows Shth (1983) who defines rural as total population minus the five largest citles and three metropolitan countries. Effectively excludes all clties over 250,000 as well as two suburban counties surrounding Taipel. Economically active - all persons over 15 . Women's participation 33 percent versus 79 percent for men.

Rural - sanitary districts and non-municipal areas 1.e., all non-urban areas. Urban - citles over 50,000; towns over 10,000 and density over 3,000 per square kllometer or which contain an administrative seat; and communes established as appropriate and without regard to sizo. Economically active - all persons over 11 . Women's participation - 65 percent versus 77 percent for men.

4/ This conception of the rural economic transformation draws on a wealth of antecedent views, most explicitly expressed by Johnston and Kilby (1975), but also drawing on Anderson and Leiserson (1980), Anthony et al. (1979) and Binswanger (1983), Byerlee and Elcher (1974), Lledholm (1973), and Vyas and Mathal (1978).

5 African rural nonfarm entrepreneurs commonly hire or apprentice 50 to 70 percent of their workers from outside the family (Aluko, 1972 and 1973; Malaw1, 1980; MIlimo and Fisseha, 1986; Mozambique, 1983; Rwanda, 1978; Tanzania, 1982; Wilcock and Chuta, 1982; Williams and McClintock, 1981; all data reported In Haggblade, Hezell and Brown, 1987, Table 13). In agriculture, nonfamily labor usage averages closer to 15-20 percent of total farm employment (E1cher and Baker, 1982; Byerlee, 1980; Anthony et al., 1979; Cleave, 1974; Collier and Lal, 1986; Collier, Radwan and Wargwe, 1986; Ghal and Radwan, 1983b; Mation et al., 1979; Norman, 1972; Norman, Pryor and Gibbs, 1979; Oates, 1984; Robertson and Hughs, 1978; Spencer and Byerlee, 1976; and WeInrich, 1975). Combining these estimates with the labor force data in Table 1, we estimate that about 20 percent of Africa's rural labor force is channeled through labor markets (60 percent of nonfarm workers $x$ a 15 percent employment share +15 percent of agricultural labor $x$ an 85 percent rural employment share -22 percent of rural enployment). Further evidence indicates that exchange labor rarely exceeds five percent of labor flows (H111, 1977; ILO 1985b and 1985c; Norman, Pryor and Gibbs, 1979; Oates, 1984; WeInrich, 1975). 
6) See Adeyomo, 1985; Aluko et.al., 1972 and 1973; Child, 1977; Liedholm and Chuta, 1976; Olufokunb1, 1981; Schadler, 1968 and Thoml and Yankson, 1985. Their data are reproduced in Haggblade, Hazell and Brown, 1987.

I See Haggblade, Hazell and Brown's (1987) analysis of data from Zambia, (Milimo and Fisseha, 1986) and Sierra Leone (Liedholm and Chuta, 1976).

8) Kilby (1987) has also begun looking at time series data on nonfarm employment in Kenya. However, his analysis ts not readily comparable with the others cited here, because his data track only "Informal sector" firms, essentially those employing between one and nine workers. While important on employment and equity grounds, trends in informal nonfarm activity may not be representative of the entire rural nonfarm economy given that the "Informal sector" accounts for only about 20 percent of nonfarm activity (Ndua and $\mathrm{Ng}^{\prime}$ ethe, 1984).

2/ Vanvali's data are reproduced in Haggblade, Hazell and Brown (1987).

10) Table 1 indicates that between 7 and 30 percent of the African rural labor force engages in nonfarm activity as a secondary source of employment, with agriculture presumably their primary occupation. Farm management data indicate this secondary employment may be even higher. The data cited earlier (Section III.A) indicate that 15 to 65 percent of farmers engage in nonfarm activities at certain seasons of the year. Given that farm employment typically accounts for 85 percent of rural employment, this leads to an estimated 13 (15 $x .85)$ to 42 percent $(65 \times .85)$ of the rural labor force with secondaxy nonfarm employment. We must add to that the flip side of the coln, the primarily nonfarm workers who work seasonally in agriculture, to arrive at the total share of the rural labor force moving seasonally between farm and nonfarm activities. Given that as much as 75 percent of rural nonfarm workers may participate in agriculture (Mbith1 and Chege, 1973), this results in an additional 7.5 to 15 percent of the rural laborforce (.75 × 10 to 20 percent primarily engaged in nonfarm activity). Thus the total flow lies between about 15 ( 7 . $+7.5)$ and 57 percent $(42+15)$. Within this interval, we believe that 20 to 40 percent represents the most 1 ikely norm.

11. Considerable evidence indicates that 60 percent of rural consumption involves cash purchases, while the remaining 40 percent derives from own consumption of home-produced food (see Section V.A). Combining this with rural consumption data from Slerra Leone (KIng and Byerlee, 1977) and Nigerla (Hazell and Roell, 1983) results in the following stylized disaggregation of rural consumption: 40 percent non-marketed, home-produced food; 30 percent purchases of locally produced food; 5 percent imported foods; and 25 percent nonfood goods and services. Given these parameters, the share of locally produced food in total rural cash expenditure stands at 50 percent $[30, ; 30+5+25)]$. Specific computation for Sierra Leone results in a 40 percent estimate: while use of the Gusau, Nigeria data leads to an estimate of 58 
percent. Thus 50 percent probably represents a reasonable average.

12) The model is a two-sector, semi-input-output model in which the output of tradables is given exogenously, and the output of nontradables is elastic and is determined by the region's demand for nontradables. The demand for nontradables consists of household demand, which is assumed to be a linear function of regional value added (or income), and nontradable production Intermediates, which are assumed to be proportional to reglonal gross output. Within this model, the regional value added multiplier for a one unit increasi in value added from tradables Is $1 /(1-\alpha-\beta \nu)$, where $\beta$ is consumers' marginal budget share for nontradables, $\alpha$ is producers' nontradable intermediate inputs as a ratio of gross regional output, and $\nu$ is the ratio of value added to gross regional output.

13/ These results are not strictly Keynesian multipliers (a.s in Section VII B). Rather they are derived as ratios of the changes in farm and nonfarm income arising from policy-induced movements along the production frontier.

14J See Ashe, 1985; Blayney and Otero, 1985; Deures, 1981; Farbman, 1981; Goldmark, Rosengard and Mooney, 1982; Goldmark et al., 1982; Goldmark and Rosengard, 1983 and 1985; Haggblade, 1982; Hunter, 1980; Kilby, 1979, 1982 and 1987; Kilby and Bangasser, 1978; Kilby and d'Zmura, 1985; Lassen, Traore, Brown and Walton, 1985; Levitsky, 1985; Liedholm, 1985; and Livingstone, 1977 and 1980. Liedholm and Mead (1987) provide a particularly succinct recent distillation of the findings of the small enterprise evaluation 11terature.

15. Lele (1986) reaches this same conclusion through a different chain of reasoning. 
Tab1e 1: Primary Buployment in African Rural

Nonfarm Enterprises

(percent)

c o u n t r y
Rural Labor

Force Employed in Nonfarm Enterprises a/ Total Male Femāle

\section{A. Primary simployment}

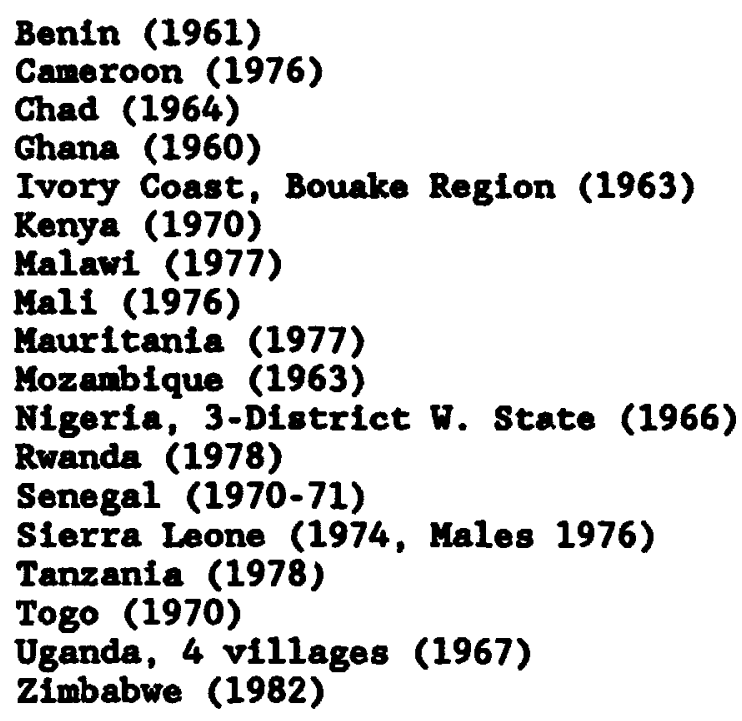

B. Secontary Employment

Benin (1961)

Chad (1964)

Western Nigerla, 3 states (1966)

Sierra Leone (1976)

Tanzania (1980)

Zambia, 2 regions

\begin{tabular}{|c|c|c|}
\hline 41 & 10 & 77 \\
\hline 10 & . & - \\
\hline 3 & 4 & .1 \\
\hline 27 & 13 & 89 \\
\hline 10 & $\cdots$ & -. \\
\hline 28 & 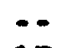 & -- \\
\hline 11 & 17 & 4 \\
\hline 8 & $\therefore$ & - \\
\hline 21 & $\cdots$ & -. \\
\hline 9 & 19 & 1 \\
\hline 63 & 19 & 87 \\
\hline 5 & $\cdots$ & -- \\
\hline 18 & -- & $\ldots$ \\
\hline 14 & 19 & - \\
\hline 6 & 10 & 2 \\
\hline 26 & -- & - \\
\hline 20 & $\cdots$ & - \\
\hline 20 & $\cdots$ & $\cdots$ \\
\hline
\end{tabular}

a/ See Note 3 for Individual sountry definitions of rural.

Sourees: Benln: Dopublique du D.hemey (1004)

Cenrocen: Ropubltque Unde du Conerom (1970)

Ched: Ropublique du Tched (1966)

Thena: Chene (1904)

Ivary Coast: Ropublique de Cote d'twoire (1005)

reaya: Ino. (1972), clted in Chrute and Ltedboln (1070) Malew1: Malawi Covernent (1980)

Nall: Ropolblique de Nall (1980)

Mardtenia: Ropublique de veurltenle (1979)

Hosemblque: Ropublioe Populer do Hosmblque (1083)
Migeris: theller and rovorins (1070)

Duranda: Dende (1078)

8cnocal: Ropublique du Benorel (1073)

81erxe Leone: Hale (1076) exom Byerlee, ot el, (1977

Arrregate Exan Thome (1083)

Tensenle, 1078: Onfted Ropiblic of Tensenta (1982

Tensenie, 1980: Colller ot al. (1988)

Usanda: Lremdt, ot al. (1072)

2embia: Bodlund and Landehl (2003)

Zimbabue: Zinbabe (1085) 
Table 2: Share of Nonfarm Earninge in Total Rural Incone in Sub-Saharan Africa

(percent)

\begin{tabular}{|c|c|c|}
\hline Country & $\begin{array}{l}\text { Agricultural } \\
\text { Incone }\end{array}$ & $\begin{array}{l}\text { Nonfarm } \\
\text { Incone }\end{array}$ \\
\hline \multicolumn{3}{|c|}{ A. Total Rural Incone } \\
\hline $\begin{array}{l}\text { Botswana (1974-75) } \\
\text { Ghana, Akwapin (1965-66) } \\
\text { Ghana, Eastern Region (1967-68) } \\
\text { Ghana, Heads of Household in E. Region } \\
\text { Ghana, Five Villages } \\
\text { Ivory Coast, South East Region (1963) } \\
\text { Kenya (1969) } \\
\text { Kenya (1976) } \\
\text { Lesotho (1977-78) } \\
\text { Northern Nigeria, Kano Region } \\
\text { Northern Nigeria, Zaria Region } \\
\text { Sierra Leone (1974) } \\
\text { Slerra Leone (1975-76) } \\
\text { Tanzania (1969) } \\
\text { Tanzania (1975) }\end{array}$ & $\begin{array}{l}56-75 \\
58-72 \\
58-82 \\
25-50 \\
70-84 \\
71 \\
69 \\
72 \\
23 \\
72 \\
78 \\
64 \\
81 \\
79 \\
77\end{array}$ & $\begin{array}{l}24-44 \\
14-28 \\
18-42 \\
50-75 \\
16-30 \\
29 \\
31 \\
28 \\
77 \text { a/ } \\
28 \\
22 \\
36 \\
19 \\
21 \\
23\end{array}$ \\
\hline $\begin{array}{l}\text { Ghana, Akwapin (1965-66) } \\
\text { Ghana, Cocoa Farmers (1968-70) } \\
\text { Ghana, Eastern Region (1967-68) } \\
\text { Ghana, Heads of Household in E. Region } \\
\text { Ivory Coast, Bouake Region (1970) } \\
\text { Liberia, Western Region (1973) } \\
\text { Tanzania (1969) } \\
\text { Tanzania (1975) } \\
\text { Zambla, Luapuala Province (1977) } \\
\text { Zambia, Three Provinces (1982) }\end{array}$ & $\begin{array}{l}55-78 \\
77 \\
45-68 \\
17-45 \\
58-76 \\
69 \\
64 \\
57 \\
79 \\
76\end{array}$ & $\begin{array}{l}22-45 \\
23 \\
32-55 \\
55-83 \\
24-42 \\
31 \\
36 \\
43 \\
21 \\
24\end{array}$ \\
\hline
\end{tabular}

a Remittances account for $2 / 3$ of rural incone. Domestic nonfarm income is 12 percent of total, or 34 percent of domestic rural value added.

8ouree: Botewana: Cherniohovaly ot al. (1005) p.S1

Ghma: Ilo (19925), pp. 51, 53, 54, 57; Ilo (1985e)

Ivory Const: Ivory Coast (1087)

Kenye: Ino (1982s)

Lesotho: Mational Accounts, olted in Ino (1982h) p. 16

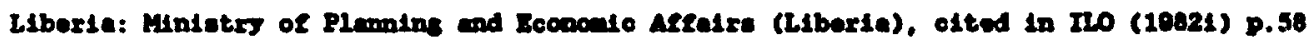

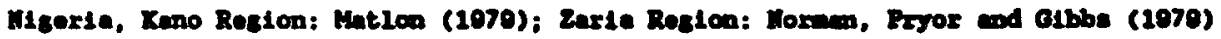

slerre Leone: Chute and Lledholn (1070)

Imsenia: Ino (1982a)

Usenda: Massell and Parnos (1969) p.315

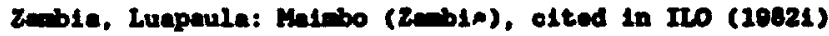

2mble, Three Provinces: Due and Mindende (2005) 
Trbles: Magnitude and Compontesion of

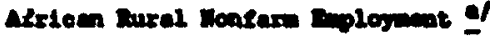

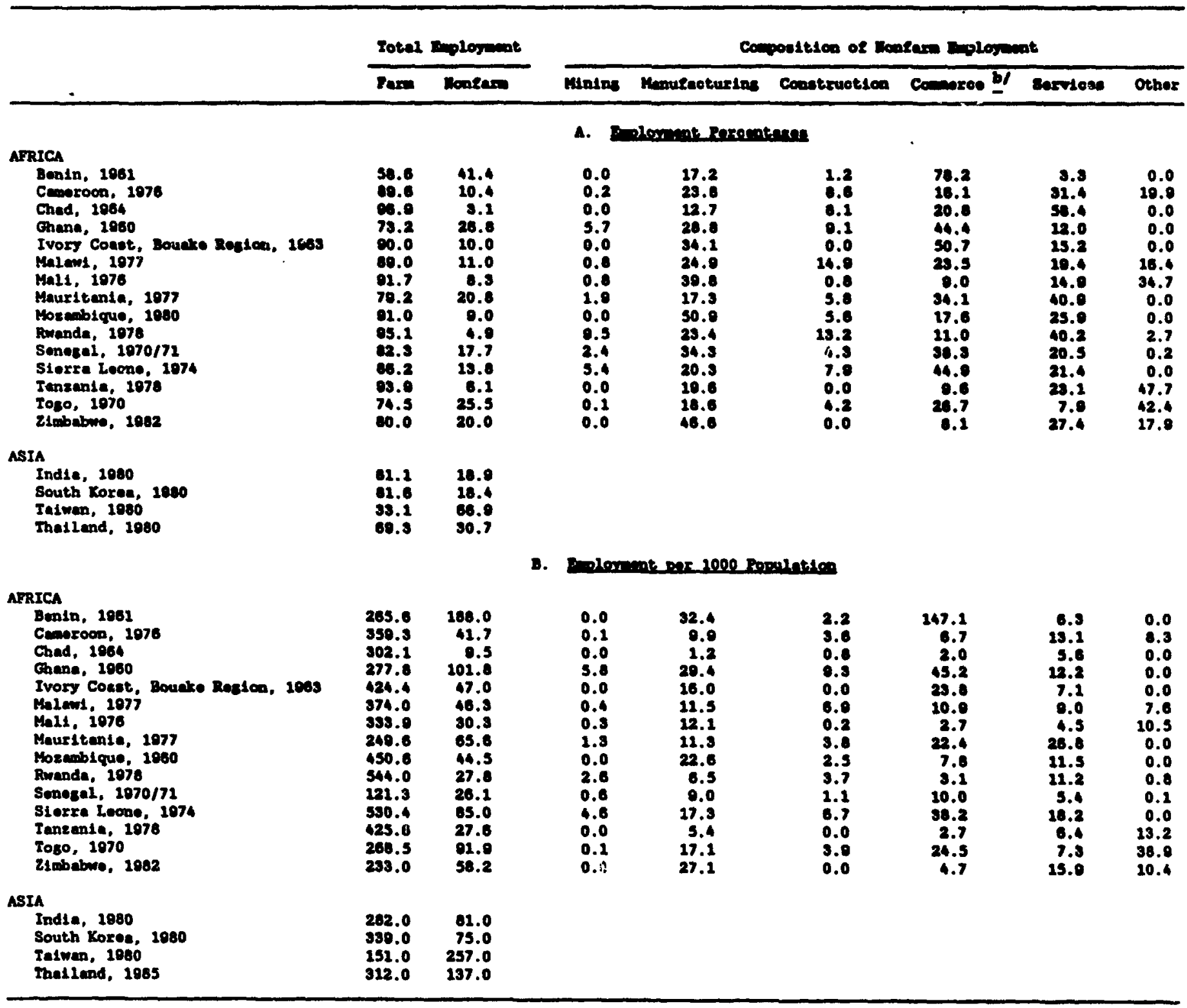

If Seo Note 3 for Individual comtry definitions of rural and of the workforce.

b) Includes transport.

Sources: Bentn: Ropubligue du Dehones (1006)

Canoroon: Ropublique du Cemoroun (1070)

Ched: Ropublique du Tohad (1068)

Chann: Chene (1004)

Irory Costt: Ropubleque de cote d'Irolre (1085)

Halmol: Malewt Covernont (1080)

Ma11: Me11 (1000)

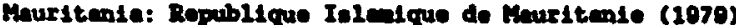

Kosmbique: Ropublice Bopular de Moecbique (2003)

Dwanda: Dorande (1978)

8enoge1; Ropublique du Seangel (1073)

Blerra Leope: Thone (1003)

Tensenie: Obited Ropoiblic of Imsenie (1902)

Togo: Toso (1974)

Zibolbwe: zimbabe (1095)
Indle: Indie (1081)

South Korea: Woren (1080) and 1090b)

Ielwen: Shit (1093) and Chine (1042)

Thallend: Thallend (1985) 
Table 4: Activity Breakdown of

Rural Manufacturing Employment (percent)

\begin{tabular}{|c|c|c|c|c|c|}
\hline Iten & $\begin{array}{c}\text { Burkina } \\
\text { Faso } \\
1980\end{array}$ & $\underset{1986}{\text { Zambla b/ }}$ & $\underset{1977}{\text { Kenya }}$ & $\begin{array}{l}\text { N1gerfa d } \\
1972 / 73\end{array}$ & $\begin{array}{l}\text { Slerra } \\
\text { Leone } \\
1976\end{array}$ \\
\hline $\begin{array}{l}\text { Food/Agricultural } \\
\text { Processing }\end{array}$ & 55 & 55 & 22 & 2 & $5 \underline{21}$ \\
\hline Clothing Procucts & 25 & 6 & 22 & 56 & 53 \\
\hline Wood Products & 1 & 32 & 43 & 11 & 19 \\
\hline Metal Products & 8 & 4 & 6 & 4 & 19 \\
\hline Other & 21 & 3 & 7 & 27 & 4 \\
\hline
\end{tabular}

a/ Bastern ORD, 1980.

b/ Six Rural Provinces, 1986.

\& Central Province Village Centers, 1977.

d/ Four States, 1972/73; enterprise, not employment percentages.

e/ A11 Rural, 1976.

ff Includes only bakeries.

Source: Burkina Faso: Wilcock and Chuta (1982); firms below 50 persons.

Kenya: Norcliffe, Freeman, and Miles (1984), cited in Liedholn and Mead (1986); firms below 50 persons.

Nigeria: Aluko et al. (1972 and 1973); firms below 50 persons. enterprise, not employment percentages.

Sierra Leone: Liedholm and Chuta (1976); firms below 50 persons. Zambia: Milimo and Fisseha (1986). 


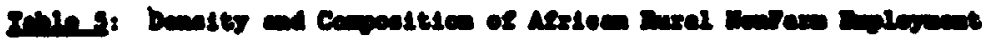

by des of rearuts

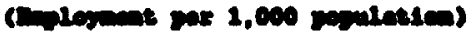

\section{Ena-crestevileme}

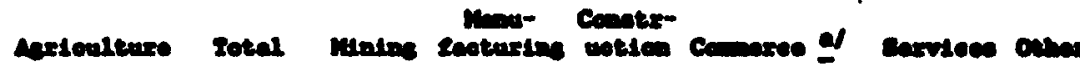

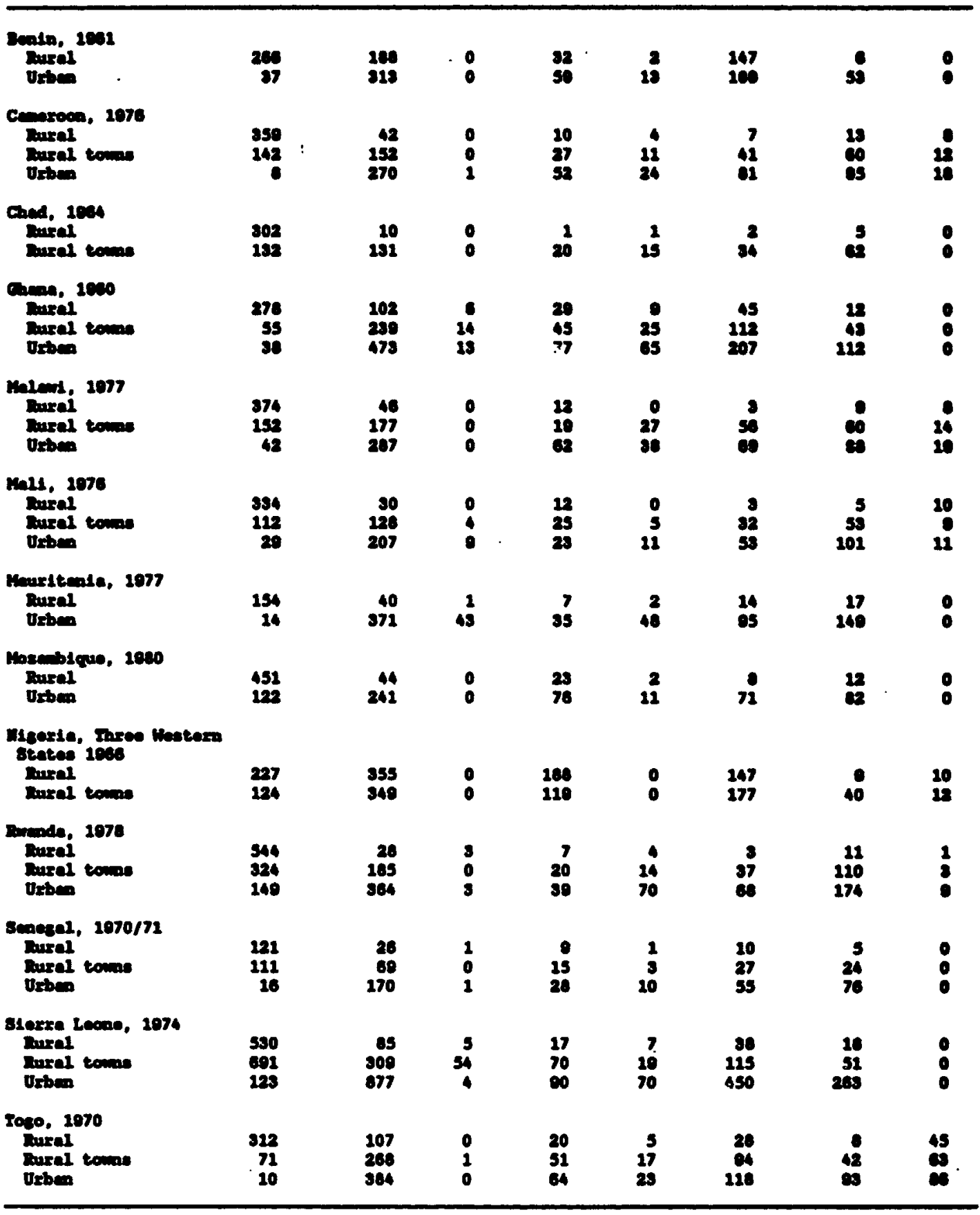

I Includes tranport.

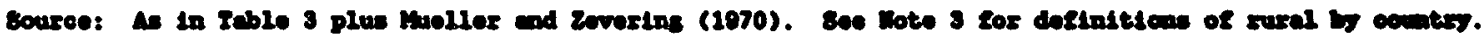


Table 6: Spatial D1stribution of Rural Manufacturing Bouake Region, Ivory Coast, 1970

(Employment per 1,000 Population)

\begin{tabular}{|c|c|c|c|c|c|c|}
\hline \multirow[t]{2}{*}{$\begin{array}{c}\text { Type of } \\
\text { Manufacturer }\end{array}$} & \multicolumn{6}{|c|}{ K11oweters fron Bouake a/ } \\
\hline & $0-10$ & $10-15$ & $15-20$ & $20-25$ & $25+$ & Region \\
\hline Basketnakers & 6.24 & 8.75 & 16.42 & 19.46 & 40.74 & 11.71 \\
\hline Weaver: & 9.73 & 11.70 & 13.76 & 15.72 & 17.75 & 10.14 \\
\hline Potters & 2.65 & 4.62 & 3.83 & 3.38 & 4.22 & 2.97 \\
\hline Bulldera (cement) & 2.75 & 2.86 & 1.89 & 1.77 & 1.90 & 1.79 \\
\hline Bulldars (banco) & 1.68 & 1.76 & 2.21 & 1.25 & 1.06 & 1.33 \\
\hline Dyer: & 0.00 & 0.53 & 2.30 & 6.79 & 1.90 & 1.58 \\
\hline Tallore & 1.56 & 1.19 & 2.30 & 1.53 & 1.48 & 1.24 \\
\hline Wood carving & 0.59 & 1.35 & 0.86 & 0.64 & 1.06 & 0.74 \\
\hline Carpentry & 0.59 & 0.33 & 0.54 & 0.88 & 0.84 & 0.43 \\
\hline Shoemakers & 0.00 & 1.47 & 0.09 & 0.00 & 0.84 & 0.43 \\
\hline Hechanics & 0.25 & 0.20 & 0.90 & 0.76 & 0.42 & 0.40 \\
\hline Blackent the & 0.25 & 0.25 & 0.63 & 0.64 & 0.23 & 0.31 \\
\hline Jewelers & 0.00 & 0.08 & 0.00 & 0.12 & 2.74 & 0.25 \\
\hline Hairuressers & 0.00 & 0.00 & 0.14 & 0.00 & 0.00 & 0.03 \\
\hline Total & 26.21 & 35.27 & 46.00 & 53.06 & 75.24 & 33.37 \\
\hline
\end{tabular}

a) Bouake had a population of 110,000 in 1970.

Source: Ancey (1974), P.116 
Table 7: Rates of Growth in Nonfar- Employment by Locality $51 z e$

Sierra Leone, 1974-1980

(percent compound growth)

\begin{tabular}{|c|c|c|c|}
\hline \multirow{2}{*}{ Activity } & \multicolumn{3}{|c|}{ Locality Size } \\
\hline & $2,000-20,000$ & $20,000-250,000$ & $250,000 t$ \\
\hline $\begin{array}{l}\text { Repaira } \\
\text { Radio } \\
\text { Motor vehicle } \\
\text { Watch }\end{array}$ & $\begin{array}{l}15.0 \\
22.0 \\
17.0 \\
2 /\end{array}$ & $\begin{array}{r}5.2 \\
19.2 \\
2.4 \\
a /\end{array}$ & $\begin{array}{l}15.0 \\
\frac{b}{20} 0.0 \\
13.0\end{array}$ \\
\hline $\begin{array}{l}\text { Food Processing } \\
\text { Bakery } \\
\text { Other }\end{array}$ & $\begin{array}{r}14.0 \\
3.4 \\
39.0\end{array}$ & $\begin{array}{l}33.0 \\
14.0 \\
\mathrm{~b} /\end{array}$ & $\begin{array}{l}21.0 \\
32.0 \\
a /\end{array}$ \\
\hline $\begin{array}{l}\text { Woodwork } \\
\text { Carving } \\
\text { Carpentry } \\
\text { Other }\end{array}$ & $\begin{array}{r}0.5 \\
0.0 \\
-0.6 \\
\text { b/ }\end{array}$ & $\begin{array}{l}8.8 \\
b / 8.6 \\
a /\end{array}$ & $\begin{array}{r}7.6 \\
24.0 \\
3.6 \\
0.0\end{array}$ \\
\hline $\begin{array}{l}\text { Clothing } \\
\text { Tailoring } \\
\text { Tie Dyeing } \\
\text { Shoemaking } \\
\text { Other }\end{array}$ & $\begin{array}{r}0.7 \\
0.0 \\
-3.0 \\
-4.3 \\
-4\end{array}$ & $\begin{array}{r}1.8 \\
3.8 \\
-8.5 \\
16.0 \\
a /\end{array}$ & $\begin{array}{r}5.0 \\
4.9 \\
a / .9 \\
6.2 \\
0.0\end{array}$ \\
\hline $\begin{array}{l}\text { Metalwork } \\
\text { Welding } \\
\text { Blacksmithing } \\
\text { Goldsmithing } \\
\text { Other }\end{array}$ & $\begin{array}{r}-5.8 \\
0.0 \\
-5.5 \\
a / \\
0.0\end{array}$ & $\begin{array}{r}9.4 \\
23.0 \\
1.8 \\
a / \\
0.0\end{array}$ & $\begin{array}{r}10.0 \\
6.6 \\
22.0 \\
a / \\
0.0\end{array}$ \\
\hline other Manufacturing & a/ & 7.2 & b/ \\
\hline
\end{tabular}

af Greater than zero but less than one percent.

b/ Value for 1974 is zero.

Source: Chuta and Lledholn (1982), pp. 104-105. 


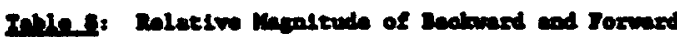

Mextoulteural Ligheges in turel afficen

\begin{tabular}{|c|c|c|c|c|c|c|c|c|c|c|c|}
\hline & \multicolumn{4}{|c|}{ 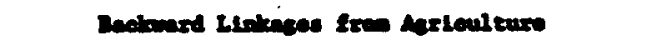 } & \multicolumn{6}{|c|}{ Tornard Listages fren Merleulture } & \multirow[b]{2}{*}{ 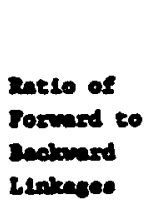 } \\
\hline & Dlemeat & 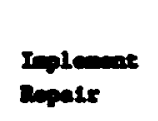 & 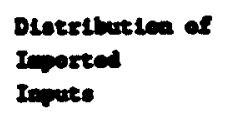 & Iotal & $\begin{array}{l}\text { Jood } \\
\text { Procenesins }\end{array}$ & Dasteurantes & Dotohere & $\begin{array}{l}\text { Latetbox- } \\
\text { woxk }\end{array}$ & $\begin{array}{l}\text { Destribution } \\
\text { end } \\
\text { storaye }\end{array}$ & Totel & \\
\hline \multicolumn{12}{|c|}{ 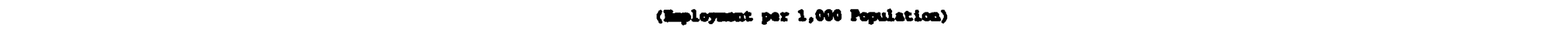 } \\
\hline \multicolumn{12}{|l|}{ 2omese (1505) } \\
\hline 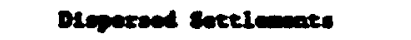 & -- & 3.2 & $\cdots$ & 3.2 & 44.0 & 0.0 & $\cdots$ & 0.4 & $4.7 \pm$ & 49.2 & 25 \\
\hline 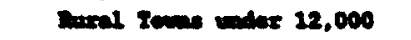 & -- & 3.2 & $\cdots$ & 1.2 & 38.3 & $1 . \bullet$ & - & $0 . \bullet$ & $28.6=1$ & 6.5 & 53 \\
\hline Treal I00, 22,000-50,000 & -- & 2.4 & -- & 1.4 & 19.9 & 1.3 & -- & 0.6 & $26.7=1$ & 30.3 & 36 \\
\hline Iocal Bural & -- & 2.7 & -- & 2.7 & 39.0 & 0.2 & -- & 0.4 & $7.6=$ & 46.0 & 27 \\
\hline \multicolumn{12}{|l|}{ slates Leme (1976) } \\
\hline Sotel amates 2,000 & -- & 3.5 & -- & 3.5 & $0.0 \mathrm{~b}$ & -- & -- & - & - & $\cdots$ & -- \\
\hline Inseal Tomas, $5,000-20,000$ & - & 0.7 & -- & 0.7 & $0.0 \mathrm{~g}$ & -- & $\cdots$ & $\cdots$ & $\cdots$ & - & -- \\
\hline \multicolumn{12}{|c|}{ 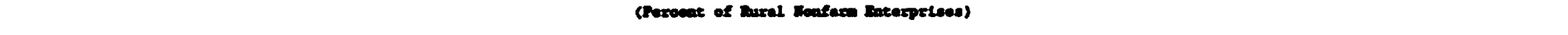 } \\
\hline Inese (19m) & & & & & & & & & & & \\
\hline Ceneral seovines & 0.2 & 3.5 & 2.1 & 7.8 & 3.8 & -- & 4.3 & 3.8 .1 & 5.1 d & 19.1 & 2.5 \\
\hline
\end{tabular}

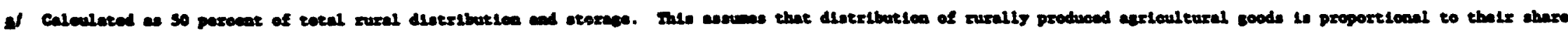

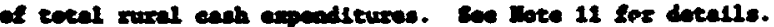

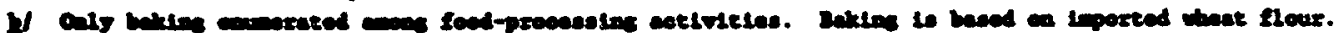

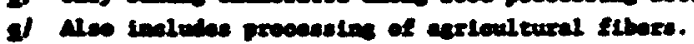

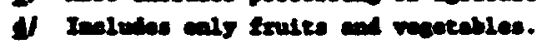

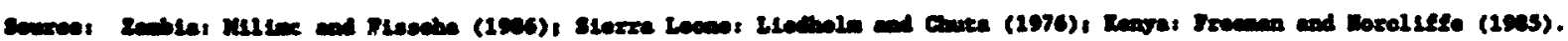




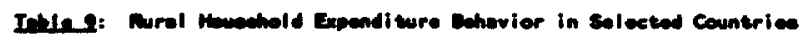

\begin{tabular}{|c|c|c|c|c|c|c|c|c|c|c|c|c|c|c|c|}
\hline \multirow[b]{2}{*}{$\cdot$} & \multicolumn{5}{|c|}{ Averese Anect thare } & \multicolumn{5}{|c|}{ Mrainal audeot sthare } & \multicolumn{5}{|c|}{ Expendi ture Elesticitice } \\
\hline & M.Mienris & $\begin{array}{l}\text { Aurel } \\
\text { sierra } \\
\text { Leme }\end{array}$ & $\begin{array}{l}\text { Zoire } \\
\text { Prevines } \\
\text { N.Nleneits }\end{array}$ & $\begin{array}{l}\text { nud } \\
\text { noteroile }\end{array}$ & $\begin{array}{l}\text { Nons } \\
\text { Arewt } \\
\text { s.radit }\end{array}$ & $\begin{array}{l}\text { anowe } \\
\text { M.Micepite }\end{array}$ & $\begin{array}{l}\text { Dural } \\
\text { sierne } \\
\text { Leme }\end{array}$ & $\begin{array}{l}\text { Zoire } \\
\text { Prowince } \\
\text { N.Miceris }\end{array}$ & $\begin{array}{l}\text { Nute } \\
\text { notereis }\end{array}$ & $\begin{array}{l}\text { North } \\
\text { Arees } \\
\text { S. Indie }\end{array}$ & M.Nientie & $\begin{array}{l}\text { Pural } \\
\text { sierre } \\
\text { Leme }\end{array}$ & $\begin{array}{l}\text { Zoire } \\
\text { Previnee } \\
\text { M.Wiecrio }\end{array}$ & $\begin{array}{l}\text { mis } \\
\text { nolaveie }\end{array}$ & $\begin{array}{l}\text { North } \\
\text { Areos } \\
\text { S.Indis }\end{array}$ \\
\hline \multicolumn{16}{|l|}{ 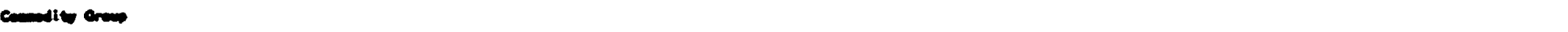 } \\
\hline 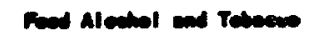 & $\boldsymbol{e . 7}$ & $\pi .7$ & w.5 & $\omega .7$ & $\pi .2$ & 70.2 & 67.9 & - & 87.7 & $\boldsymbol{\infty} .0$ & 0.4 & 0.82 & - & 0.87 & 0.01 \\
\hline Clentive end Fentomer & 7.2 & 7.0 & 11.4 & B.e & 4.8 & $\mathbf{s . \bullet}$ & 7.4 & - & $\bullet .2$ & 7.7 & 2.24 & 2.00 & - & $1 . n$ & 1.6 \\
\hline 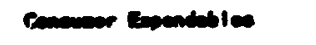 & 4.8 & $\cdot$ & $\cdot$ & 3.4 & 3.2 & 4.4 & $\cdot$ & - & 8.7 & 2.4 & 1.02 & - & - & 1.08 & $0 . \pi$ \\
\hline Mosing & 0.8 & $\cdot$ & s.e & 4.2 & ๓.». & 0.4 & $\cdot$ & - & 12.4 & n.e. & 1.40 & $\cdot$ & - & 9.02 & n.๑ \\
\hline Trmaneret & 1.9 & 2.2 & 2.8 & 1.0 & 2.0 & 2.7 & $\$ .0$ & - & $\mathbf{2 . 2}$ & 8.4 & 1.41 & 1.25 & - & 1.07 & 1.22 \\
\hline anosiles & 1.1 & $\cdot$ & 2.1 & 0.6 & 1.4 & $\cdot$ & 7.1 & - & 1.0 & 1.26 & $\mathbf{s . 2 8}$ & 8.48 & - & $\cdot$ & $\cdot$ \\
\hline Eneotien and Henth & 1.2 & 1.4 & $\cdot$ & $\mathbf{2 . 0}$ & 1.0 & 1.6 & 0.8 & - & 6.2 & 2.4 & 1.6 & 0.67 & - & 1.70 & 1.28 \\
\hline 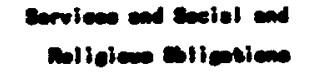 & 9.8 & 4.8 & 28.6 & $\mathbf{2 0 . 2}$ & 9.1 & $\$ .4$ & 8.1 & - & 2.7 & 18.8 & 1.8 & 1.60 & - & $1 . \pi$ & 2.22 \\
\hline | & & & & & & & & & & & & & & & \\
\hline | (2) & $\pi .8$ & $\mathbf{\omega . 0}$ & • & 4.4 & $\boldsymbol{\omega . 0}$ & 70.8 & $\omega .1$ & - & 24.6 & $\infty .8$ & $0 . \omega$ & 0.98 & - & 0.0 & 0.7 \\
\hline 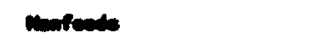 & $\bullet .4$ & 22.6 & $\cdot$ & 10.1 & 17.4 & 11.8 & 17.0 & - & $\boldsymbol{* . \bullet}$ & $\boldsymbol{\infty}$ & 1.24 & 1.41 & - & 2.06 & $1 . \pi$ \\
\hline renter & 5.4 & 6.0 & - & $\mathbf{0 . 8}$ & 18.8 & s.e & 1.0 & - & 10.1 & 12.0 & 1.07 & 0.28 & - & 0.1 .8 & $0 . \omega$ \\
\hline 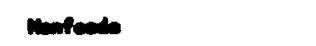 & 10.0 & 18.4 & . & 18.8 & 7.4 & 12.6 & 14.8 & - & $\mathbf{0 . 4}$ & $\mathbf{e . \bullet}$ & 1.20 & 1.07 & - & 1.68 & 1.17 \\
\hline
\end{tabular}

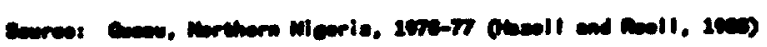

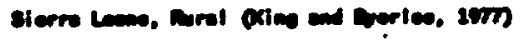

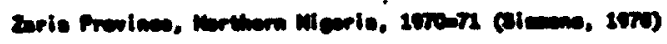

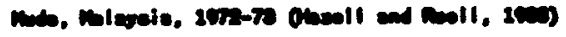

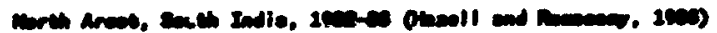


Figure 1

Rural ${ }^{1}$ Nonfarm Employment

as a Function of GNP/Capita

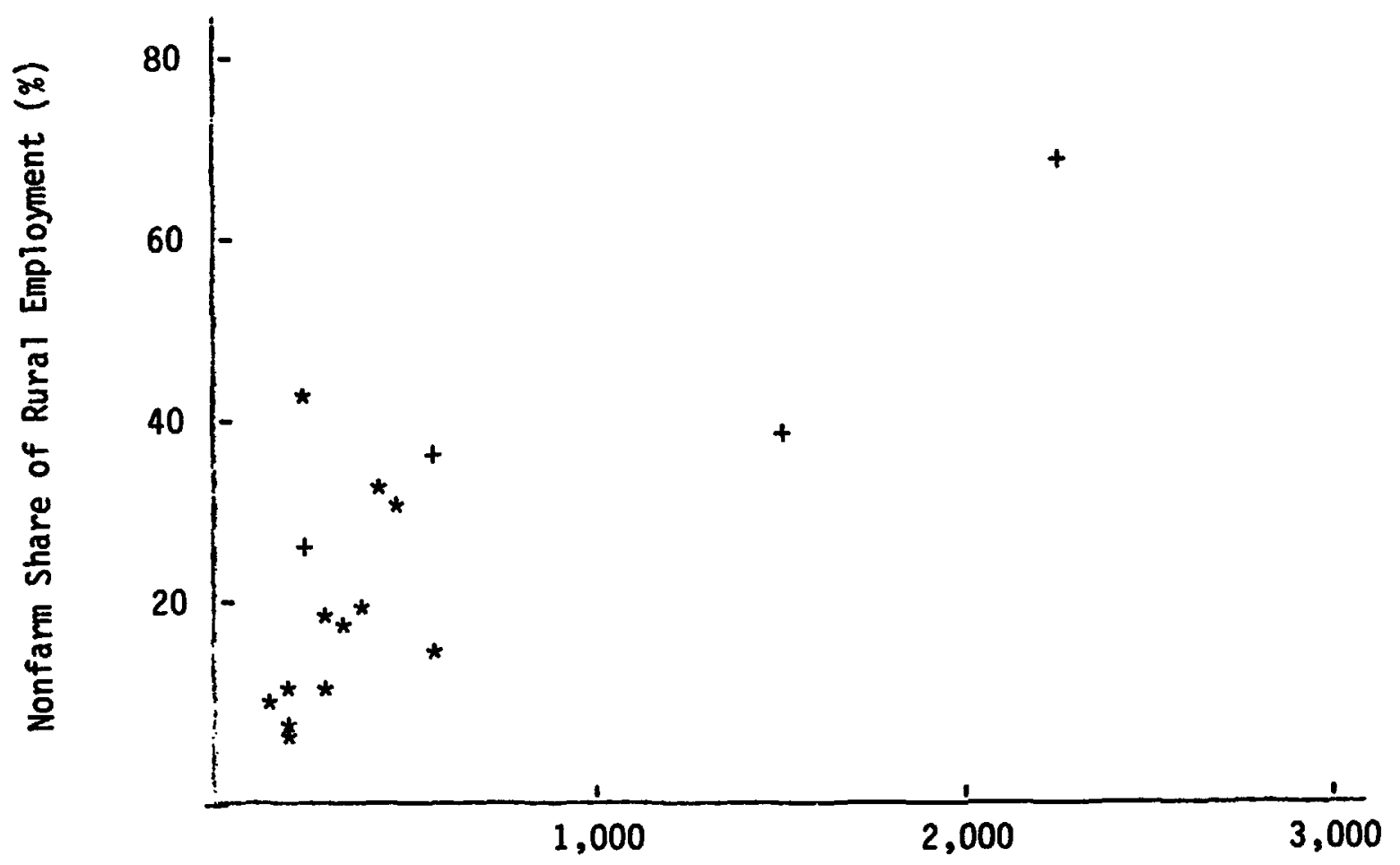

Gross National Product per Capita ( $\$ 1980)$

Note 1: Rural includes rural towns up to 250,000 in size,

* Africa.

+ Asia.

Source: See Table 3. 
Figure 2

Rural ${ }^{1}$ Nonfarm Employment

as a Function of Agricultural Income

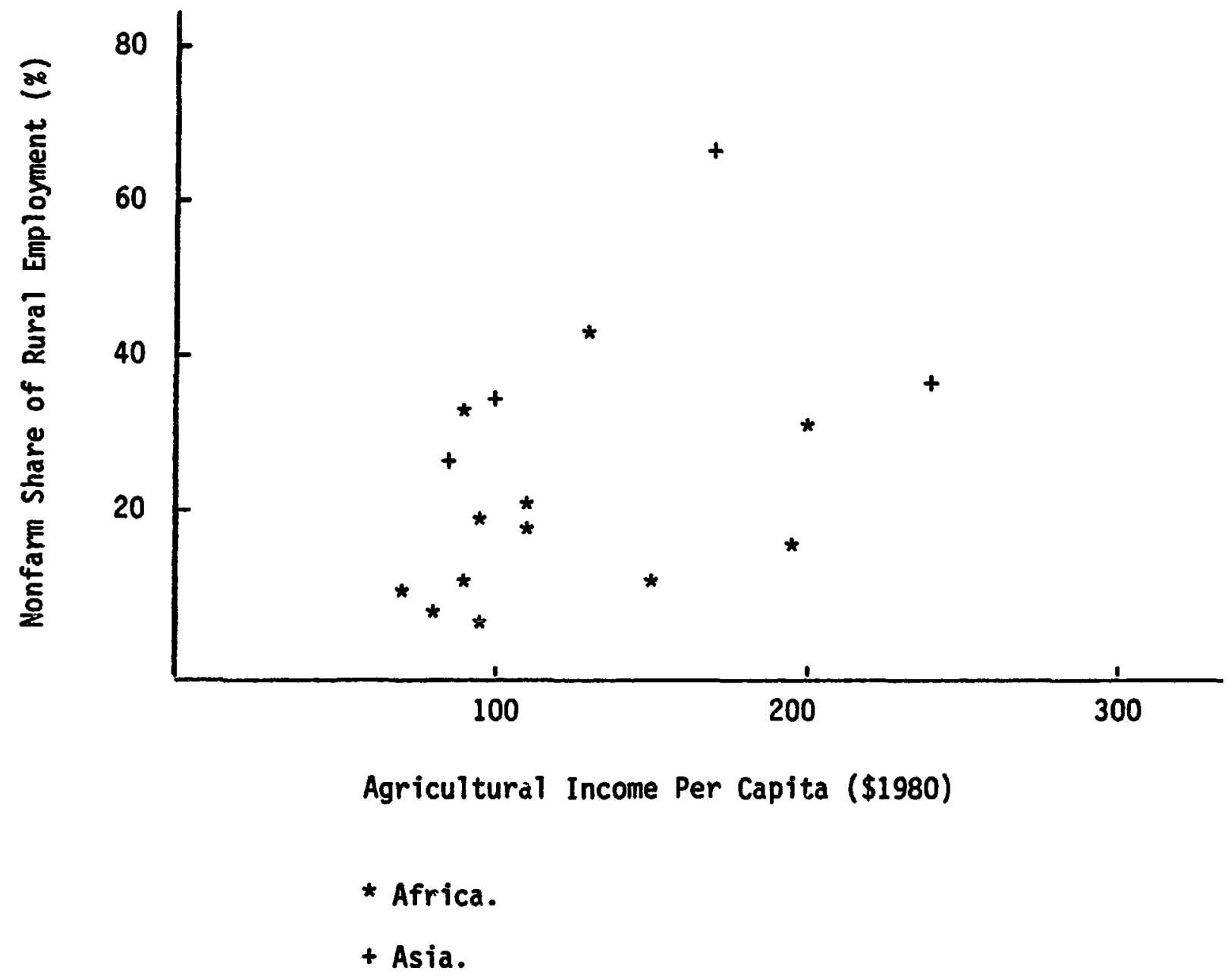

Note 1 Rural includes rural towns up to 250,000 in size. Source: As in Table 3. 
Figure 3
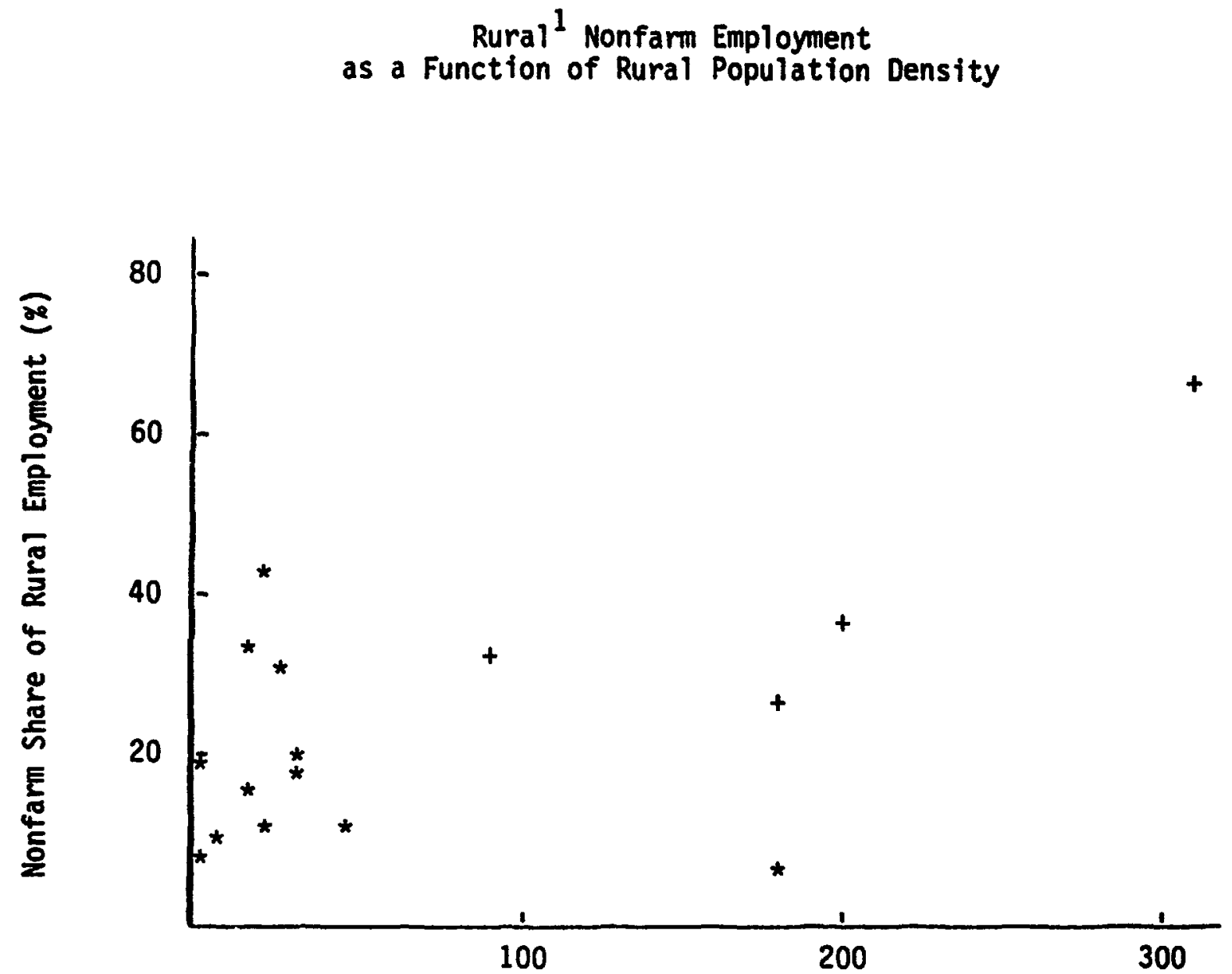

Rural Population Density per Square Kilometer

* Africa.

+ Asia.

Note 1: Rural includes rural towns up to 250,000 in size. Source: As in Table 3. 
Figure 4

Population Density and Nonfarm Employment in Seven Districts, Anambra State, Nigeria

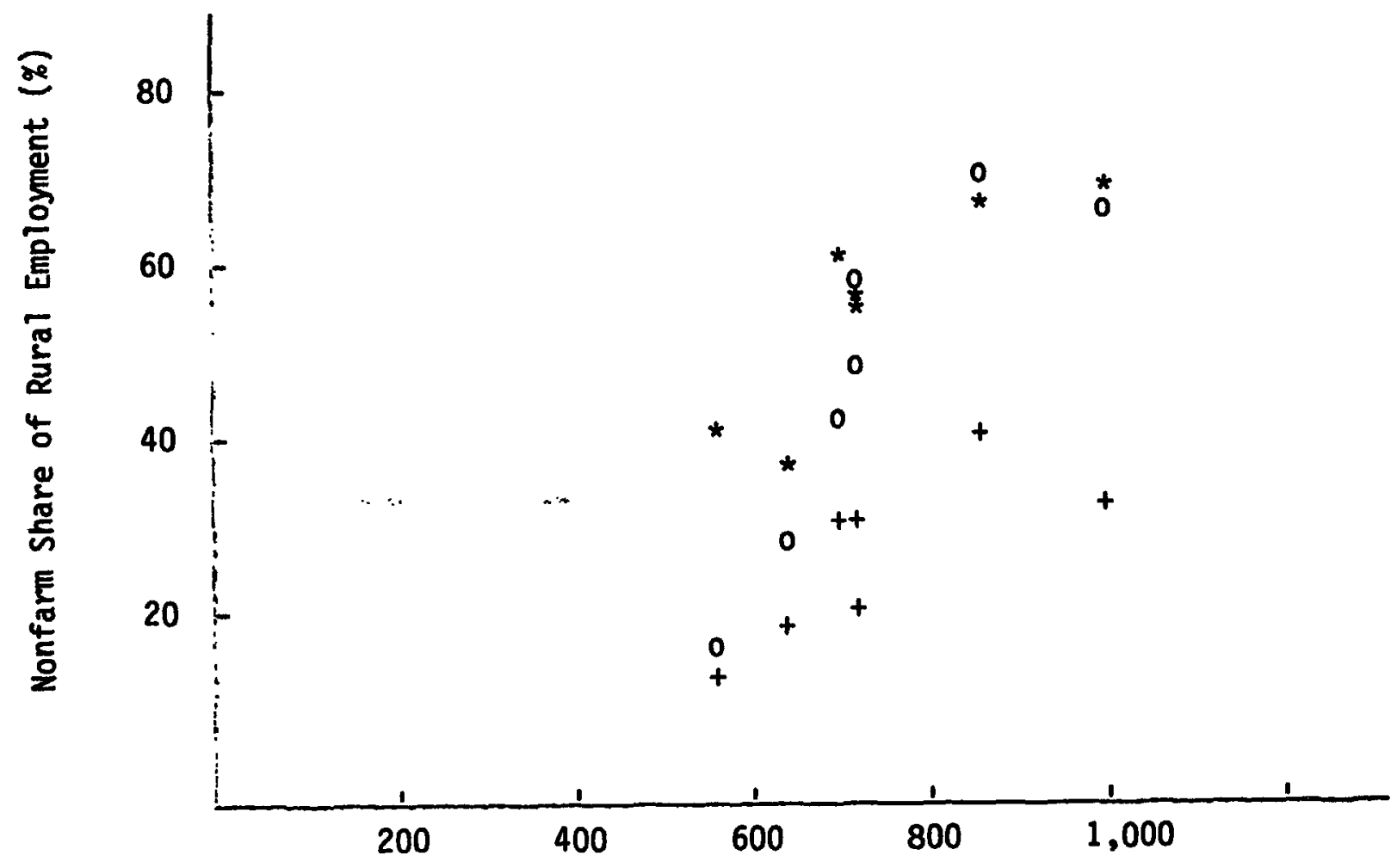

Rurai Population Density per Square Kilometer

* Men.

o Women.

+ Children.

Source: Okafor (1983). 


\section{REFERENCES}

Adelman, Irma. 1984. "Beyond Export-Led Growth." World Development 12 (9): $937-49$.

Adesimi, A.A. 1983. "Capital Formation in Traditional Agriculture: A Case Study of Farm Households in Ondo State of Nigeria," Savings and Development 7(2): 151-161.

Adeyemo, Remi. 1983. "Credit as an Input in Marketing: A Study of the Nature and Use of Credit by Food Marketers in Anambra State of Nigeria," Savings and Development 7(1): 63-73.

Aluko, S.A.; Oguntoye, O.A.; and Afonja, A.0. 1972. Small Scale Industries: Western State of Nigeria. Ile-Ife: Industrial Research Unit, University of Ife.

Aluko, S.A.; Oguntoye, O.A.; and Afonja, A.0. 1973. Small Scale Industries: Midwestern, Kwara and Lagos State. ITe-Ife: Industrial Research Unit, University of Ife.

Ancey, Gerard. 1974. Relations de voisinage ville-campagne. Une analyse appliquee en Bouake: sa couronne et sa region (cote d'Ivotre). Paris, ORSTOH, Memoires ORSTOM No. 70.

Anderson, Dennis and Leiserson, Mark. 1980. "Rural Non-Farm Employment in Developing Countries." Economic Development and Cultural Change. (January), pp. 227-248.

Andrae, Gunt1la. 1981. Industry in Ghana: Production, Form, and Spatial Structure. Uppsala, Sweden: Scandinavian Institute of African studies.

Anthony, K.R.M., Johnston, B.F., Jones, W.O. and Uchendu, V.C. 1979. Agricultural Change in Tropical Africa. Ithaca: Cornell University Press.

Ashe, Jeffrey. 1985. The PISCES II Experience: Local Efforts in MicroEnterprise Development. 2 Vols. Washington, D. C.: U.S. Agency for International developmesit.

Be11, Clive; Haze11, Peter and Slade, Roger. 1982. Project Evaluation in Regional Perspective: A Study of an Irrigation Project in Northwest Malaysia. Baltimore: The Johns Hopkins University Press.

Berry, Sara S. 1975. Cocoa, Custom and Socio-Economic Change in Rural Western Nigeria. Oxford: Clarendon Press.

Binswanger, Hans P. 1983. "Agricultural Growth and Rural Nonfarm Activities." Finance and Development (June):38-40. 
Blayney, Robert G. and Otero, Maria. 1985. "Small and Micro-Enterprises: Contributions to Development and Future Directions for AIDS Support." Washington, D.C.: Employment and Enterprise Development Division. Bureau of Science and Technology. USAID.

Boomgard, James J.; Davies, Stephen P.; Haggblade, Steve, and Mead, Donald C. 1986. "Subsector Analysis: Its Nature, Corduct and Potential Contribution to Small Enterprise Development." East Lansing: Michigan State University, Department of Agricultural Economics. MSU International Development Working Paper No. 26.

Botswana, Government of. 1976. The Rural Income Distribution Survey in Botswana 1974/75. Gabowne, Botswana: Central Statistics Office, Winistry of Finance and Development Planning.

Bouman, F.J.A. 1977. "Indigenous Savings and Credit Societies in the Third World: A Message." Savings and Development 1(4):184-214.

Brandt, Hartmut; Gerken, Elbert and Schubert, Bernd. 1972. The Industrial Town as a Factor of Economic and Sociai Development: The Example of Junja, Uganda. Wunchen: Weltforum, Verlag.

Byerlee, Derek. 1973. "Indirect Employment and Income Distribution Effects of Agricultural Development Strategies: A Simulation Approach Applied to Nigeria." East Lansing: Michigan State University, Department of Agricuitural Economics. African Rural Employment Paper No. 9.

Byerlee, Derek. 1980. "Rural Labor Markets in West Africa with Emphasis on the Semi Arid Tropics." in ICRISAT, "Proceedings of the International Workshop on Socioeconomic Constraints to Development of Semi-Arid Tropical Agriculture, 19-23 February 1979, Hyderbad, India. pp.348-356.

Byerlee, Derek and Eicher, Carl K. 1974. "Rural Employment, Migration and Economic Development: Theoretical Issues and Empiricai Evidence from Africa," in Agricultural Policy in Developing Countries. N. Islam, ed. New York: Macmíllan, pp. 273-313.

Bylerlee, Derek; Eicher, Carl; Liedholm, Carl and Spencer, Dunstan, S.C. 1977. "Rural Employment in Tropical Africa: Summary of Findings." African Rural Economy Working Paper No. 20. East Lansing, MI: Michigan State University.

Cameroun, Republique Unie. 1976. Recensement General de la Population et de l'Habitat d'Auril, Vol. 1. Yaounde, Cameroun: Bureau Central du Recensement.

Chernichovsky, Dov; Lucas, Robert E.B. and Mueller, Eva. 1985. "The Household Economy of Rural Botswana: An African Case." Washington D.C.: World Bank. Staff Working Paper No. 715. 
Child, Frank C. 1977. "Smal1-Scale Rural Industry in Kenya." Los Angeles: University of California. African Studies Center Occasional Paper No. 17.

China, Republic of. 1982. An Extract Report on the 1980 Census of Population and Housing, Taiwan-Fukin Area, Republic of China. Taipei: Population Census office of the Executive Yuan.

Chuta, Enyinna and Liedholm, Car1. 1979. "Rural Non-Farm Employment: A Review of the State of the Art." East Lansing: Michigan State University, Department of Agricultural Economics. MSU Rural Development Paper No. 4.

Chuta, Enyinna and Liedholm, Car1. 1982. "Employment Growth and Change in Sierra Leone Smal1-Scale Industry, 1974-80." International Labour Review 121(1):101-113.

Cleave, John H. 1974. African Farmers: Labour Use in the Development of Small-holder Agriculture. New York: Praeger.

Collier, Paul and La1, Deepak. 1986. Labour and Poverty in Kenya, 19001980. Oxford: Clarendon Press.

Collier, Paul; Radwan, Samir, and Wangwe, Samuel; with Albert Wagner. 1986. Labour and Poverty in Rural Tanzania. Oxford: Clarendon Press.

Congo, Repub1ique Democratique de. 1968. Enquete sur les entreprises industrielles, agricoles, commerciales et de service. Kinshasa, Zaire: Winistere de T'Economie Nationale.

Cote d'Ivoire, Republique de. 1965. Etude Regionale de Bouake 1962-1964: la Synthese generale. Abidjan, Iiry Coast: Ministere du Plan.

Cote d'Ivoire, Republique de. 1967. Region du Sud-Est, Etude Socioeconomique: les Comptes Economiques. Paris: Societe d'Etudes pour Te Development Economique et Sociat.

Dahomey, Republique du. 1964. Enquete Demographique au Dahomey, 1961, Resultats Definitifs. Paris: Republique Francaise, Ministere de la Cooperation, IISEE.

Delancey, Mark K. 1978. "Savings and Credit Institutions in Rural West Africa: Introduction." Rural Africana 2(Fall):1-8.

Delgado, Christopher L. 1979. "The Southern Fulani Farming System in Upper Volta: A Model for the Integration of Crop and Livestock Production in the West African Savannah." East Lansing: Michigan State University, Department of Agricultural Economics. African Rural Economy Paper No. 20. 
Delgado, Christopher L. 1984. "The Role of Science and Policy in Alleviating Long-Run Food Production Problems in Africa." (Mimeo) Paper presented atthe 67th meeting of the Board for International Food and Development (BIFAD), Washington, D.C., Dec. 5.

Devres, Inc. 1981. "Small Scale Enterprise (SSE) Development: A Summary of Descriptions and Evaluations of SSE Projects and an Assessment of Approaches Used in SSE Development by AID, the World Bank and Other Funding Agencies." Washington, D.C.: Devres.

Due, Jean M. and Mindenda, Timothy. 1985. "Women's Contributions to Farming Systems and Household Income in Zambia." East Lansing: Michigan State University. Office of Women in International Development. Working Paper No. 85.

Eicher, Carl K. and Baker, Doyle C. 1982. "Research on Agricultural Development in Sub-Saharan Africa: A Critical Survey." East Lansing: Michigan State University, Department of Agricultural Economics, MSU. International Development Paper No. 1.

Erasmus, Charles T. 1956. "Culture, Structure and Process: The Occurrence and Disappearance of Reciprocal Farm Labor." Southwestern Journal of Anthropology 12: 444-469.

Farbman, M. 1981. The Pisces Studies: Assisting the Smallest Economic Activities of Urban Poor. Washington, D.C.: USAID.

Fluitman, Fred. 1983. "The Socio-Economic Impact of Rural Electrification in Developing Countries: A Review of Evidence." Geneva: World Employment Programme Working Paper, WEP 2-22/WP. 126.

Food and Agriculture Organization. 1986. African Agriculture: The Next 25 Years. Rome, FAO.

Freeman, Donald B. and Norcliffe, G.B. 1985. "Rural Enterprise in Kenya: Development and Spatial Organization of the Nonfarm Sector." University of Chicago, Department of Geography. Research Paper No. 214.

Ghai, Dharam and Radwan, Samir. ed. 1983a. Agrarian Policies and Rural Poverty in Africa. Geneva: ILO.

Ghai, Dharam and Radwan, Samir. 1983b. "Growth and Inequality: Rural Development in Malawi, 1964-78." in Dharam Ghai and Samir Radwan ed. Agrarian Policies and Rural Poverty in Africa. Geneva: ILO.

Ghana, Census Office. 1964. 1960 Popoulation Census of Ghana. Accra, Ghana.

Gibb, Arthur. 1974. "Agricultural Modernization, Non-Farm Employment and Low Level Urbanization: A Case Study of a Central Luzon Sub-Region." Ph.D. Thesis, University of Michigan. 
Goldark, Susan; Deschamps, Jean-Jacques; Recinnos, Joseph; and Glover, Beatrice. 1982. An Inpact Evaluation of The Industrial Bank of Peru's Rural Development Fund. Washington, U.C.: vevelopment Atternatives, Inc.

Goldmark, Susan; Mooney, Timothy and Rosengard, Jay. 1982. Aid to Entrepreneus: An Evaluation of the Partnership for Productivity Project in Upper Volta. Washington, U.t.: Development Alternatives, Inc.

Goldmark, Susan and Rosengard, Jay. 1983. "Credit to Indonesian Entrepreneurs: An Assessment of the Badan Kredit Kecamatan Program. Washington, D.C.: Development Alternatives Inc.

Goldwark, Susan and Rosengard, Jay. 1985. A Manual to Evaluate SmallScale Enterprise Development Projects. Washington, D.C.: U.S. Agency for International Development, Progran Design and Evaluation Methods, Report No. 6.

Haggblade, Steve. 1982. Rural Industrial Officer's Handbook. Gaborone, Botswana: Mintstry of Comerce and Industry.

Haggblade, Steve; Hazell, Peter; and Brown, James. 1987. "Farm Nonfarm Linkages In Rural Sub-Saharan Africa: Empirical Evidence and Policy Implications." Washington, D.C.: World Bank. Agriculture and Rural Development Deparment Discussion Paper No. ARU 67.

Haggblade, Steve; Liedholm, Carl and Mead, Donald, C. 1986. "The Effect of Policy and Policy Reform on Non-Agricultural Enterprises and Employment in Developing Countries: A Review of Past Experiences." East Lansing: Michigan State University, Department of Agricuitural Economics, MSU. International Development Working Paper No. 27.

Haugerud, Angelique. 1984. "Household Dymamics and Rural Political Economy Among Emba Farmers in the Kenya Highlands." Ph.D. Dissertation, Northwestern University.

Haze11, Peter B.R. 1984. "Rural Growth LInkages and Rural Development Strategy." (Mimeo) Washington, D.C.: International Food Policy Research Institute. Paper prepared for the Fourth European Congress of Agricultural Economics, Kiel, Germany, September 3-7, 1984.

Haze11, Peter B.R.; Ramasamy, C. and Rajagopalan, V. forthcoming. "An Analysis of the Growth Linkage Effects of Agricultural Agricultural Growth on the Reglonal Economy." in Peter Hazell and C. Ramasamy ed. Technological Change and Rural Welfare: A Study of the High Yielding Rice Varteties in !ami! Nadu, Indta. Washington, O.C.: IFt?I.

Hazell, Peter and Ramasamy, C. 1986. "Household Expenditure Patterns and the Growth of the Nonfarm Economy." (Mimeo) Paper presented at the IFPRI/TNAU Workshop on Growth LInkages, Oatacanund, India, Feb. 14$16,1986$.

Hazell, Peter, B.R. and Roell, Alisa. 1983. "Rural Growth Linkages: Househoid Expenditure Patterns in Malaysia and Nigerla." Washington, D.C.: International Food Policy Research Institute. Research Report No. 41. 
Hedlund, Hans and Landahl, Muts. 1983. Migration and Change, Rural Zambia. Uppsala, Sweden: The Scandinavian Institute of African Studies.

Hill, Polly. 1977. Rural Housa: A Village and Setting. Cambridge, England: Cambridge University Press.

Hirschman, A.0. 1958. The Strategy of Economic Development. New Haven, CT: Yale University Press.

Hunter, John. 1979. "The Successful and the Unsuccessful Enterprise: An Analysis of Fifty Small Business Enterprises Supported by the Botswana Enterprises Development Unit." Gaborone, Botswana: Institute of Development Management.

India. 1981. Census of India 1981: Series 1, Paper 3, Provisional Population Totals, Workers and Non-Workers. New Delhi: Office of the Registrar General and Census Commissioner.

International Labour Office. 1972. Employment, Incomes and Equality: A Strategy for increasing Productive Employment in Kenya. Geneva: ILO.

I.L.0. 1979. Poverty and Employment in Rural Areas of Developing Countries. Geneva: ILO. Advisory Committee on Rural Development, Ninth Session, 27 November - 6 December 1979.

I.L.0. 1982a. Basic Needs in Danger: A Basic Needs Oriented Development Strategy for Tanzania. Addis Ababa: ILo. Job and Skiths Programme for Africa.

I.L.0. 1982b. Disparites de revenus entre les villes et les campagnes au Cameroun. Job and SkitTs Program for Africa (JASPA). Addis Abeba: ILO.

I.L.0. 1982c. Disparites de revenus entre les villes et les campagnes au Mali. Job and Skiths Program for Africa (JASPA). Addis Abeba: ILO.

I.L.0. 1982d. Disparites de revenus entre les villes et les campagnes au Togo. Job and SkitTs Program for Africa (JASPA). Addis Abeba: ILO.

I.L.0. 1982e. Disparites de revenus entre les villes et les campagnes en Afrique noire francophone: rapport de synthese. Job and Skitts Program for Africa (JASPA). Addis Abeba: ILO.

I.L.0. 1982f. Rural-Urban Gap and Income Distribution (A Comparative SubRegional Study): The Case of thana. Addis Ababa: ILO. Job and Skiths Programme for Africa.

I.L.0. 1982g. Rural-Urban Gap and Income Distribution (A Comparative SubRegional Study): The Case of Kenya. Addis Ababa: ILO. Job and Skitis Programe for Africa. 
I.L.0. 1982h. Rural-Urban Gap and Income Distribution (A Comparative SubRegional study): The Case of Lesotho. Addis Ababa: ILO. Job and SktIIs Programme for Africa.

I.L.0. 1982i. Rural-Urban Gap and Income Distribution (A Comparative SubRegional Study): The Case of Liberla. Addis Ababa: ILO. Job and Skiths Programme for Africa.

I.L.0. 1982j. Rural-Urban Gap and Income Distribution (A Comparative SubRegional study): The Case of Lambia. Addis Ababa: ILO. Job and skitTs Programme for Africa.

I.L.0. 1983. Patterns of Industrialization and Impact on Employment and Incomes in African Countries: The Case of Kenya. Addis Ababa: ILO. Job and Skitls Programme for Africa.

I.L.0. 1985a. Informal Sector in Africa: Jobs and Skills Programe for Africa. Addis Ababa: ILo.

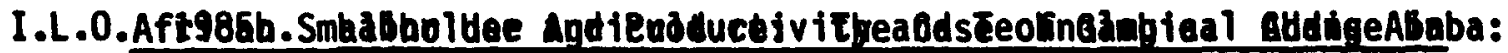
ILO. Job and Skills programme for Africa.

I.L.0. 1985c. Labor Use and Productivity and Technological Change in African Smatholder Agriculture: The Case of Sudan. Addis Ababa: ILO. Job and SkTITs Programe for Africa.

I.L.0. 1985d. Labor Use and Productivity and Technological Change in African SmalTholder Agriculture: The Case of Uganda. Addis Ababa: ILO. JOb and Skills programme for Africa.

I.L.0. 1985e. Labor Use and Productivity and Technological Change in African Smaltholder Agricutture: The Case of Ghana. Addis Ababa: ILO. Job and SkTlls Programe for Africa.

Johnston, Bruce F. and Kilby, Peter. 1975. Agriculture and Structural Transformation: Economic Strategies in Late-Developing Countries. Condon: Oxford University Press.

Kilby, Peter. 1962. The Development of Small Industry in Eastern Nigeria. Lagos, Nigeria: TSAID.

Kilby, Peter. 1979. "Evaluating Technical Assistance." World Development $7(3)$.

Kilby, Peter. 1982. "Small Scale Industry in Kenya." East Lansing: Michigan Sta ce University, Department of Agricultural Economics. MSU Rural Development Series Working Paper No. 20.

Kilby, Peter. 1987. "Small-Scale Manufacturing in Kenya," (mimeo) Washington, D.C.: Smithsonian Institution, The Wilson Center. 
Kilby, Peter and Bangasser, P. 1978. "Assessing Technical Cooperation: The Case of Rural Industry." International Labour Review. 117:

Kilby, Peter and D'Zmura, David. 1985. "Searching for Benefits." Washington, D.C.: U.S. AID. Evaluation Special Study No. 28.

Kilby, Peter and Liedholm, Carl, 1986. "The Role of Nonfarm Activities in the Rural Economy." Employment and Enterprise Development Policy Analysis Discussion Paper \#7. Cambridge, MA: Harvard Institute for International Deveiopment.

King, Robert P. and Byerlee, Derek. 1977. "Income Distribution, Consumption Patterns and Consumption Linkages in Rural Sierra Leone." East Lansing: Michigan State University, Department of Agricultural Economics; African Rural Economy Paper No.16.

King, Robert P. and Byerlee, Derek. 1978. "Factor Intensities and Locational Linkages of Rural Consumption Patterns in Rural Sierra Leone." American Journal of Agricultural Economics (May): 197-206.

Kitching, G.N. 1977. Economic and Social Inequality in Rurai East Africa: The Present as a Clue to the Past. Monograph No. 1. Swansea: University of Swansea, Centre for Devlopment Studies.

Korea, Republic of. 1980a. 1980 Population and Housing Census Report: Volume 1, Complete Enumeration, Whole Country. Seoul: National Bureau of Statistics, Economic planning Board.

Korea, Republic of. 1980b. 1980 Population and Housing Census Report: Volume 2, Fifteen Percent Sample Survey, Economic Activity. Seoul: National Bureau of Statistics, Economic Planning Board.

Kreamer, Ross G. 1986. "Gari Processing in Ghana: A Study of Entrepreneurship and Technical Change in Troptcal Africa." Cornell International Agrticultural Economics Study, AE Research 86-30. Ithaca, New York: Cornell University, Department of Agricultural Economics.

Krishna, Raj. 1976. Rural Unemployment: A Survey of Concepts and Estimates for India. Staff Working Paper No.234. Washington, D.C.: World Bank.

Lassen, Cheryl; Traore, Richard; Brown, Alex and Walton, Joshua. 1985. "Credit and Enterprise Development Training That Reach The Small Producer Majority in Burkina Faso: Midterm Evaluation of Association pour la Productivite/Burkina Faso." Washington, D.C.: Partnership for Productivity.

Lee, Eddy. 1983. "Export-led Rural Development: The Ivory Coast." in Dharam Ghai and Samir Radwan ed. Agrarian Policies and Rural Poverty in Africa. Geneva: ILO. 
Lele, Uma. 1986. "Women and Structural Transformation." Economic Development and Cul tural Change 34(2):195-221.

Leurquin, P. P. 1960. Le niveau de vie des populations rurales du Ruanda Urundi. Paris: Editions Nauvelaerts.

Levitsky, Jacob. 1986. World Bank Lending to Small Enterprises: A Review. Washington, D.C.: World Bank, Industry and Finance Series, Volume 16.

Liedholm, Car1. 1973. "Research on Employment in the Rural Non-Farm Sector in Africa." East Lansing: Michigan State University, Department of Agricultural Economics. African Rural Economy Paper No. 5.

Liedholm, Carl. 1985. "Small Scale Enterprise Credit Schemes, Administrative Costs and the Role of Inventory Norms." East Lansing: Michigan State University, Department of Agricultural Economics, MSU International Development Working Paper No.25.

Liedholm, Carl and Chuta, Enyinna. 1976. "The Economics of Rural and Urban Smal1-Scale Industries in Sierra Leone." East Lansing: Michigan State University, Department of Agricultural Economics. African Rural Economy paper No. 14.

Liedholm, C. and Chuta, Enyinna. 1982. "Employment Growth and Change in Sierra Leone Smail-Scale Industry: 1974-80." International Labour Review, 121:

Liedholm, Carl and Mead, Donald C. 1986. "Small-Scale Industry in Africa: An Overview." in Robert J. Berg and Jennifer S. Whitaker, eds. Strategies for African Development. Berkeley, CA: University of California Press.

Liedholm, Carl and Mead, Donald. 1987. "Small-Scale Industries in Developing Countries: Empirical Evidence and Policy Implications." East Lansing: Michigan State University.

Livingstone, Ian. 1977. "Rural Indutries for Developing Countries: An Evaluation of Kenya's Rural Industrial Development Programme." Journal of Modern African Studies 15:2 (June).

Livingstone, Ian. 1980. "Alternative Approaches to Small Industry Promotion: Tanzania, Kenya and Botswana." Gaborone, Botswana: Institute of Development Management, Occasional Paper No.7.

Luning, H.A. 1967. Economic Aspects of Low Labor-Income Farming. Wageningen, Netherlands, Centre for Agricuttural Publications and Documentation, Agricultural Research Report No.699.

Malawi Government. 1980. Malawi Population Census, 1977. Final Report, Volume II. Zombà: National statistical office. 
Malawi Government. 1984. National Sample Survey of Agriculture 1980/81, Volume III, Income and Expenditure, Crop Storage, Livestock, Resources and Nutrition. Zomba, Malawi: National Statistical office.

Ma11, Bureau de Recensement. 1980. Recensement general de la population, decembre 1976: resultats definitifs. 3 vol. Bamako, Kall.

Masse1, Benton F. and Parnes, Andres. 1969. "Estination of Expenditure Elastioities from a Sample of Rural Households in Uganda." Bulletin of The Oxford Institute of Economics and Statistics 31: 313-329.

Mation, Peter J. 1979. "Income Distribution Among Farmers in Northern Nigeria: Empirical Results and Policy Implications." East Lansing: Michigan State University, Department of Agricultural Economics. African Rural Economy Paper No. 18.

Matlon, Peter; Eponou, Thomas; Franzel, Steven; Byerlee, Derek and Baker, Doyle. 1979. "Poor Rural Households Technical Change, and Income Distribution in Developing Countries: Two Case Studies from West Africa." East Lansing: Michigan State University, Department of Agricultural Economics. African Rural Economy Working Paper No. 29.

Mauritanie, Republique Islamique de. 1979. Recensement General de la Population 1977: Volume I, Resultats Prioritaires. Nouakchott: Ministere de TEconomie et des Finances.

Mbithi, Philip M. and Chege, Fred E. 1973. "Linkages Between Agriculture and Rural Small Scale Enterprises." in Frank C. Child and Mary E. Kempe ed. Small Scale Enterprise. Occasional Paper No.6. Nairobi, Kenya: Institute of Development Studies.

Mellor, John W. 1976. The New Economics of Growth: A Strategy for India and The Developing World. Ithaca, New York: Cornell University Press.

- Mellor, John W.; Delgado, Christopher; and Blackie, Malcolm J., eds. 1987. Accelerating Food Production in Sub-Saharan Africa. Baltimora: The Johns Hopkins University Press.

ME! Ior, John W. and Johnston, Bruce F. 1984. "The World Food Equation: Interrelations Among Development, Employment, and Food Consumption," Journal of Economic Literature 22(June):524-531.

Mellor, John and Lele, Uma J. 1973. "Growth Linkages of the New Food Grain Technologies," Indian Journal of Agricultural Economics 18:1 (January-March): pp. 35-55.

Mellor, John W. and Mudahar, Mohinder S. 1974. "Modeling Agriculture, Employment and Economic Growth: A Simulation Model," Occasional Paper No.75, Employment and Income Distribution Project, Ithaca, New York: Cornell University, Department of Agricultural Economics. 
Milimo, John T. and Fisseha, Yacob. 1986. "Rural Small Scale Enterprises in Zambia: Results of a 1985 Country-Wide Survey." East Lansing, Michigan State University, Department of Agricultural Economics. MSU International Development Papers, Working Paper No. 28.

Miracle, Marvin P., Miracle, Diane F., and Cohen, Laurie. 1980. "Informal Savings Mobilization in Africa." Economic Development and Cultural Change 28:4(July):701-724.

Moore, M.P. 1975. "Cooperative Labor in Peasant Agriculture." Journal of Peasant Studies 2:270-279.

Mocambique, Republica Popular de. 1983. 1 Recc.7seamento Geral de Populacao. Maputo, Mozambique: Consetho Ccordenador de Reconseamento.

Mueller, P. and Zevering, K.H. 1969. "Employment Promotion Through Rural Development: A Pilot Project in Western Nigeria." International Labour Seview 100 (2): 111-130.

Mueller, P. and Zevering, K.H. 1970. "Socio-economic Conditions in the Ifo, Otta, and Ilaro Districts of "the Western State of Nigeris." an 1.L.0. Fact-finding Report for the Pilot Project for Rural Employment Promotion in the Western State, (nonofficial working paper). Ministry of Economic Planning and Reconstruction of the Western State of Nigeria, Ibadan.

Ndua, Gichiri and $\mathrm{Ng}$ 'ethe, Njunga. 1984. "The Role of the Informal Sector in the Development of Smail and Intermediate Size Cities: The Informal Sector in Nkuru." Working Paper No.417. Nairobi, Kenya: Institute of Development Studies.

Norman, David W. 1972. An Economic Study of Three Villages in Zaria Provice. Zaria, Nigeria, Ahmadu Bello University, Samaru FiscelTaneous paper No.37.

Norman, David W.; Pryor, David H.; and Gibbs, Chrisotpher J.N. 1979. "Technical Change and the Small Farmer in Hausaland, Northern Nigeria." East Lansing: Michigan State University, Department of Agricultural Economics. African Rural Economy Paper No.21.

Norman, David W.; Simmons, Enmy B.; and Hays, Henry M. 1982. Far,ning Systems in the Nigerian Savanna: Research and Strategies for Development. Boulder, Colorado: Westview Press.

Oates, Peter M. 1984. The Economic Environment of Farmers in Lindi and Mtwara Regions: An Rssessment of Constraints and Potential. VoT. 1 Wain Report. Surrey England: Land Resources Development Centre, Overseas Development Administration. 
Okafor, Francis C. 1983. "Rural Employment Diversification in Audinbua State, Nigeria: Its Mature and Implications for Developinent. Labour, Capital and Society, 16 (2): 226-39.

Okelo, Jasper A. 1973. "Rural Enterprise Survey in Kakamega District, Kenya." a report of the consultant to Danida (Mimeo) Nairobi, Kenya.

Olufokumbi, Banwo. 1981. "Sources of Credit to Agricultural Food Marketers in Southwestern Nigerfa." Savings and Development 5(313):189-201.

Page, John M., Jr. 1979. Small Enterprises in African Development: A Survey. Washington, D.C.: World Bank. Staff Working Paper No. 363.

Page, John M., Jr. and Steel, William F. 1984. Small Enterprise Development: Economic Issues from African Experience. Washington, D.C.: World Bank. Technical Paper No. 26.

Rangarajan, C. 1982. Agricultural Growth and Industrial Performance in India. Research Report Wo. 33. Washington, D.C.: International Food Policy Research Institute.

Robertson, A.F. and Hughes, G.A. 1978. "The Family Farm in Buganda." Development of Change $9(1978): 415-439$.

Rogers, Glenn Roy. 1986. "The Theory of Output-Income Multipliers with Consumption Linkages: An Application to Mauritania." Ph.D. dissertation, University of Wisconson, Madison.

Rondinel11, Dennis A. and Ruddle, Kenneth. 1978. Urbanization and Rural Development: A Spatial Policy for Equitable Growth. New York: Praeger.

Rondinel1i, Dennis A. 1983. Secondary Cities in Developing Countries: Policies for Diffusing Urbanization. Beverty Hitls, CA: Sage Publications.

Rwanda, Bureau National de Recensement. 1978. Recensement general de la population et de l'habitat, 1978. vol.1,2,5. Kigali, Rwanda.

Schadler, K. 1968. Crafts, Small-Scale Industries and Industrial Education in Tanzanta. Munich: Weltforum Verlag.

Senegal, Republique du. 1973. Enquete Demographique Nationale 1970-71: Analyse de Resultats du Deuxieme Passage Portant sur la Population Active. vakar: Ministere de Finances et des Affaires Economiques, Drrection de la Satistique.

Sharpley, Jennifer. 1981. "Resource Transfers Between the Agricultural and Non-Agricultural Sectors: 1964-1977," in Tony Killick ed. Papers on the Kenyan Economy: Performance, Problems and Policies. Natrobi: Heinemann. 
Shih, J.T. 1983. "Decentralized Industrialization and Rural Nonfarm Emplosment in Taiwan." Industry of Free China 60:2 (August):1-20.

Simmons, Emmy B. 1976a. Economic Research on Women in Rural Development in Northern Nigeria. OLC Paper No. 10, Washington, D.C.: Overseas Ciason Committee.

Simmons, Emmy B. 1976b. "Rural Household Expenditures in Three Villages in Zaria Province, May 1970-u1y 1971." Samaru Misacellaneous Paper 56, Institute for Agricultural Research, Ahmadu Bello University, Zaria, Nigeria.

Spencer, Dunstan S.C. and Byerlee, Derek. 1976. "Technical Changes, Labor Use, and Small Farmer Development: Evidence from Sierra Leone." American Journal of Agricultural Economics 58:874-880.

Srivastava, R.K. and Livingstone, I. 1983. "Growth and Distribution: The Case of Mozambique." in Dharam Ghai and Samir Radwan ed. Agrarian Policies and Rural Poverty in Africa. Geneva: ILO.

Steel, William F. 1977. Small-Scale Employment in Production in Developing Countries: Evidence from Ghana. New York: Praeger.

Steel, William F. 1979. "Development of the Urban Artisanal Sector in Ghana and Cameroun," Journal of Modern African Studies. 17 (Oct. 1979).

Tanzania, United Republic of. 1982. 1978 Population Census Volume VII, Basic Demographic and Socio-Economic Characteristics. Dar es Salaam, Tanzania: Ministry of Planning and Economic Affairs, Bureau of Statistics.

Tchad, Republique du. 1966. Enquete demographique au Tchad 1964 Tome II. Tableaux statistiques detailles. Parts: Republique Francaise, Secretariat d'Etat aux Affatres Etrangeres Charge de la Cooperation.

Thailand. 1985. Report of the Labor Force Survey, Whole Kingdom, Round 1 , January 1985. Bangkok: National Statistical Office.

Thomi, W.H. and Yankson, P.W.K. 1985. Small Scale Industries and Decentralization in Ghana: A Prel iminary Report on Small Scale Industries in Small and Medium Sized Towns in Ghana. Frankfurt and Accra: Institut fur Wirtschaftsund Sozialgeographie and Department of Geography.

Thomas, Armand C. 1983. The Population of Sierra Leone: An Analysis of Population Census Data. Freetown.

Togo, Ministere du Plan, Direction de la Statistique. 1974. Recensement general de la population (mars-avril 1970). 3 vol. Lome, Togo. 
Vanval1, M. 1985. "Reflexions Interrogatives sur l'Emploi Rural NonAgricole en Rwander en 1983." Kigali, Rwanda: (Mimeo) Ministre of Plan, December.

Weinrich, A.I.K.H. 1975. African Farmers in Rhodesia: 0ld and New Peasant Communities in Karangaland. New York: Oxford Universtty Press.

Wilcock, David and Chuta, Enyinna. 1982. "Employment in Rural Industries in Eastern upper Volta." International Labour Review. 121 (July/Aug.): 455-68.

Williams, K.G. and McClintock, H. 1981. Small-Scale Enterprises in Meru and Bungoma Districts, Kenya. Kenya Research Project Working Paper Ho. 1. Nottingham, England: University of Nottingham, Institute of Planning Studies.

World Bank. 1981. Accelerated Development in Sub-Saharan Africa: An Agenda for Action. Washington, D.C.: World Bank.

World Bank. 1982. Trade and Employment Policies for Industrial Development. Washington, D.C.: World Bank.

World Bank.' 1983. Thailand: Rural Growth and Employment. Washington, D.C.: World Bank.

World Bank. 1987. 1987 World Development Report. Washington, D.C.: World Bank.

Zimbabwe, Central Statistics Office. 1985. 1982 Population Census: Main Demographic Features of the Population of Zimbabwe: An Advance Report Based on a Ten Percent Sample. Harare, Zimbabwe. 


\section{WORKING PAPERS}

Agricultural Policy

Agricultural growth stimulates the rural nonfarm economy through a variety of links - some operating through production relations, others through consumer spending patterns. In Asia these links are strong: a $\$ 1$ increase in agricultural incomes will generate about 80 cents in additional rural income, mainly among suppliers of rural nonfarm goods and services. In SubSaharan Africa, however, these links are much weaker: a $\$ 1$ increase in agricultural income will generate only about 50 cents of additional rural income.

One reason for these weaker links in SubSaharan Africa is that there is less irrigation, which creates jobs in construction and maintenance. Another is the lower population density, increasing the distances to markets and diminishing the competitiveness of remote producers. A third is the pattem of household consumption, with less diversity in both food and nonfood consumption. Government policies and poor infrastructure also put brakes on the nonfarm economy.

Demand clearly is the main constraint on the rural nonfarm economy. So the first task is to get agriculture going - in short, to bring faster agricultural growth to Sub-Saharan Africa. The focus should be on small-scale farming, because of its many links to the rural nonfarm economy. The second task is to be ready when growth comes. Here are some key considerations for policy formulation and future research:

- Investment codes and related laws that discriminate against small, rural firms have to be redressed.
- The focus on small-scale, rural manufactiring has to be redirected to include services, which are among the fastest growing rural nonfarm activities.

- Rural towns, crucial for the development of the rural nonfarm economy, have to be assured of adequate economic and institutional infrastructure, especially ground transport, communications, and efficient credit and labor markets.

- Investments in rural roads and transport systems have to be adequate to ensure that villagers have casy access to rural towns.

- Investments in people's skills have to accompany the investments in infrastructure to develop all types of rural businesses.

- Direct assistance to rural nonfarm enterprises - such as credit projects, especially those for working capital - can be much more costeffective than technical assistance and projects providing modem workshop facilities.

- Because women will be key actors in the transformation of Africa's rural economy - in trading, in processing anci preparing food, and in many other services - governments and assistance agencies must explicitly recognize this role and ensure that credit schemes are open to women as well as men.

This paper is a product of the Agricultural Policies Division, Agriculture and Rural Development Department. Copies are available free from the World Bank, $1818 \mathrm{H}$ Street NW, Washington DC 20433. Please contact Cecily Spooner, room J2-084, extension 37570.

The PPR Working Paper Series disseminates the findings of work under way in the Bank's Policy, Planning, and Research Complex. An objective of the series is to get these findings out quickly, even if presentations are less than fully polished. The findings, interpretations, and conclusions in these papers do not necessarily represent official policy of the Bank. 
Title

WPS1 Imports Under a Foreign Exchange Constraint

WPS2 Issues in Adjustment Lending

WPS3 CGE Models for the Analysis of Trade Policy in Developing Countries

WPS4 Inflationary Rigidities and Stabilization Policies

WPS5 Comparisons of Real Output in Manufacturing

WPS6 Farm/Nonfarm Linkages in Rural SubSaharan Africa

WPS7 Institutional Analysis of Credit Cooperatives

WPS8 Prospects for Equitable Growth in Rural Sub-Saharan Africa
Author

Date

Cristian Moran

March 1988

Vinod Thomas

March 1988

Jaime de Melo

March 1988

Miguel A. Kiguel

Nissan Liviatan

April 1988

Angus Maddison

Bart van Ark

April 1988

Steven Haggblade

Peter B. Hazell

Jamea Brown

Avishay Braverman

J. Luis Guasch

April 1988

April 1988

Steven Haggblade

April 1988

Peter B. Hazell

For information on obtaining copies of papers, contact the Research Administrator' Office, 473-1022. 